\title{
Adult Stem Cells in Bone and Cartilage Tissue Engineering
}

\author{
António J. Salgado ${ }^{1,2, *}$, João T. Oliveira ${ }^{1,3}$, Adriano J. Pedro ${ }^{1,3}$ and Rui L. Reis ${ }^{1,3}$
}

I3B's Research Group-Biomaterials, Biodegradables and Biomimetics, University of Minho, Campus de Gualtar, 4710-057 Braga, Portugal

${ }^{2}$ Life and Health Science Research Institute, University of Minho, Campus de Gualtar, 4710-057 Braga, Portugal

${ }^{3}$ Department of Polymer Engineering, University of Minho, Campus de Azurém, 4800-058 Guimarães, Portugal

\begin{abstract}
The progressive increase in life expectancy within the last century has led to the appearance of novel health related problems, some of those within the musculoskeletal field. Among the latter, one can find diseases such as osteoporosis, rheumatoid arthritis and bone cancer, just to mention some of the most relevant. Other related problems are those that arise from serious injuries, often leading to non-recoverable critical size defects. The therapies currently used to treat this type of diseases/injuries are based on the use of pharmaceutical agents, auto/allotransplant and synthetic materials. However, such solutions present a number of inconveniences and therefore, there is a constant search for novel therapeutic solutions. The appearance of a novel field of science called Tissue engineering brought some hope for the solution of the above mentioned problems. In this field, it is believed that by combining a 3D porous template - scaffold - with an adequate cell population, with osteo or chondrogenic potential, it will be possible to develop bone and cartilage tissue equivalents that when implanted in vivo, could lead to the total regeneration of the affected area. This ideal cell population should have a series of properties, namely a high osteo and chondrogenic potential and at the same time, should be easily expandable and maintained in cultures for long periods of time. Due to its natural and intrinsic properties, stem cells are one of the best available cell types. However, after this sentence, the readers may ask, "Which Stem Cells?". During the last 10/15 years, the scientific community witnessed and reported the appearance of several sources of stem cells with both osteo and chondrogenic potential. Therefore, the present review intends to make an overview of data reported on different sources of adult stem cells (bone marrow, periosteum, adipose tissue, skeletal muscle and umbilical cord) for bone and cartilage regenerative medicine, namely those focusing on the differentiation potential of the latter as well as in vivo proof of concept of their applicability. Simultaneously novel aspects of adult stem cells biotechnology such as their immunogenic characteristics and cell expansion methodologies will also be put forward. The present review also points out on issues such as the bone and cartilage regenerative market, and gives a brief description on bone and cartilage bone biology, so the readers can have a true idea of the current state of the art, and how adult stem cells can be an added value to this field.
\end{abstract}

Keywords: Adult stem cells, Tissue engineering, Bone, Cartilage.

\section{INTRODUCTION}

The increasing demand for treatment strategies for musculoskeletal disorders has led to the emergence of novel fields of science and biotechnology, such as Tissue Engineering and Stem Cell Bioengineering, which are believed to be one of the possible alternatives to the currently methodologies in the bone and cartilage regenerative medicine field. As it will be addressed afterwards, the latter presents several problems and, therefore, approaches that more closely mimic the natural regenerative processes of the native tissues are needed.

Stem cell research will undoubtedly be involved in such novel approaches. Its research received a significative boost during the 90 's and early $21^{\text {st }}$ century, and the knowledge about them increases day by day. By definition, stem cells are undifferentiated cells with a high proliferation capability, being capable of self-renewal, multilineage differentiation and therefore, the regeneration of tissues [1]. By self-renewal

*Address correspondence to this author at the Life and Health Science Research Institute, University of Minho, Campus de Gualtar, 4710-057 Braga, Portugal; Tel: +351253604871; Fax: +351253604862; E-mail: asalgado@ecsaude.uminho.pt

$1574-888 X / 06 \$ 50.00+.00$ it is meant that these cells are able to maintain their initial cell population usually by undergoing asymmetric divisions in which one stem cell gives origin to one identical daughter stem cell and a progenitor cell that will be later committed to a lineage-specific differentiation [2,3]. By multilineage differentiation it is meant that these cells must be able to originate into more than one fully differentiated functional phenotype [1]. Among the different stem cells types, one can find different populations, with the embryonic (ES cells) and Adult Stem Cells (for the present review the acronym ASCs will be used) being those that have been commonly proposed for regenerative medicine applications.

ES cells are isolated from the inner cell mass (ICM) from the blastocyst $[4,5]$. They were primarily isolated in early 80 's from mouse embryos [6,7] and in the late 90's from human embryos $[8,9]$. These cells are considered to be pluripotent as they can differentiate in almost all cells that arise from the three germ lines, but not the embryo because they are not able to give rise to the placenta and supporting tissues $[4,5]$. Due to this broad differentiation capability, these cells have a tremendous potential to be used in regenerative medicine. An example of this is the work reported by several authors in which cardiomyocytes [10], 
hematopoietic cells [11], endothelial cells [12, 13], neurons $[14,15]$, osteoblasts [16-18], chondrocytes [19, 20], adipocytes [21, 22], hepatocytes [23, 24], pancreatic islets [25] and retinal pigmented epithelial cells (RPE) [26,27] were differentiated from ES cells. However, questions from ethical and practical nature have restrained the enthusiasm on their use of these cells for therapeutic and regenerative medicine. An example of this are the current prohibitions in several countries on the isolation of new ES cell lines from spare embryos donated by fertilization clinics. Besides the ethical questions, some issues from practical origin also need to be further addressed, such as the possible tumor formation when ES cells are implanted in vivo, or the possible immunological incompatibility of ES-cell-generated donor cells [28].

Less controversial, but equally promising are ASCs. ASCs reside in the fully differentiated or adult tissues. Up to now, ASCs were found for example in the bone marrow [29], periosteum [30, 31], muscle [32, 33], fat [34], brain $[35,36]$, skin [37] and umbilical cord [38-40], just to name a few. Theoretically, and opposed to ES cells, these cells would only be capable of producing a limited range of differentiated progeny, related to the embryonic origin of the tissue where they reside are found $[4,5]$. It is believed that their function in vivo is related with the maintenance of the functional characteristics of each specific tissue. As these cells are capable of differentiating along specific lineages and of being recruited to tissues in need, the promise for autologous or even allogenous clinical implantation in short/medium term is higher than that of ES cells. Moreover, the knowledge acquired through the years on ASCs is more vast and so fewer risks will be taken when using ASCs in reparative medicine. These cells also do not present the ethical question disclosed by the ES cells, as they can be isolated from the patient itself and at the same time, it has been shown that they might have an immunoprivileged character, which will also obviate the possible immunological problems posed by the ES cells.

The objective of the present review is to discuss the possible use of adult stem cells in bone and cartilage reparative medicine. The authors will start by giving the reader a brief insight on basic aspects such as bone and cartilage basic biology and the repair market for these two tissues, followed by a presentation and discussion on, what the authors consider to be the main sources of adult stem cells for bone and cartilage tissue engineering. Finally, important topics for the application of ASCs such as their expansion and allogeneic transplantation will be introduced.

\section{BONE AND CARTILAGE BASIC BIOLOGY}

Bone is a dynamic, highly vascularized tissue with a unique capacity to heal and remodel without leaving a scar [41]. These properties, together with its capacity to rapidly mobilize mineral stores on metabolic demand, make it the ultimate smart material. Its main role is to provide structural support to the body. Furthermore, the skeleton also acts as a mineral reservoir, supports muscular contraction, withstands load bearing and protects internal organs [41, 42]. On its side, articular cartilage is essential to normal diarthroidal joint because of its ability to reduce joint stress and surface friction [43]. It is then logical to say that major alterations in their structure due to injury or disease can dramatically alter one's quality of life.

Bone tissue in the adult skeleton is arranged in two architectural forms, trabecular, also called cancellous or spongy bone (around $20 \%$ of the total skeleton), and cortical or compact bone (around $80 \%$ of the total skeleton) [44-46], comprising a matrix that is composed of two distinct phases, inorganic (mineral) and organic. The latter comprises about $25-30 \%$ of the total matrix content, while the first one, constituted by hydroxylapatite comprises the remaining $70-75 \%$ of the matrix [1]. Further details on this topic can be found elsewhere $[41,44,47-55]$. The mechanisms of bone formation, maintenance and resorption are essentially mediated by three cell types: osteoblasts, osteocytes and osteoclasts. Each of these cells has a specific function within the bone tissue, such as matrix elaboration and mineralization (osteoblasts) [41,42,56,57], osteoid matrix calcification, blood-calcium homeostasis and "mechanosensoring" (osteocytes) [20,47] and bone resorption (osteoclasts) [1,48].

Cartilage is a supporting connective tissue that comprises most of the temporary embryonic skeleton and is made of proteins, polysaccharides and a specific cell type, the chondrocyte $[58,59]$. Furthermore, it performs additional roles in the adult organism in different areas, such as the nose, the trachea and the larynx. It consists of a matrix or intercellular substance with many spaces named lacunae, which are occupied by chondrocytes. The process of cell division tends to cage them in the closely packed lacunae forming isogenous groups. Cartilage is not a very dynamic tissue, exhibiting a low metabolic rate, which often leads to low regenerative potential causing serious problems whenever injuries take place. It is characterized by low turnover and subsequent long half-lives of the constituent structural proteins [60]. Cartilage has another peculiarity, which is its avascularity [61]. Therefore, the chondrocyte viability is dependent on the diffusion of nutrients, wastes, ions and gases through the intercellular substance from adjacent capillaries [61].

Three types of cartilage have been distinguished on the basis of the histological criteria and biomechanical properties: hyaline, elastic and fibrous cartilage [58]. Hyaline cartilage is the most predominant type $[62,63]$, appearing uniform and translucent under macroscopical observation. The physical properties of hyaline cartilage are a direct result of its extracellular matrix composition and organization, since the molecules present therein convey the capacity to withstand significant compressive forces without displaying significant deformation and provide the tissue with a very low frictional surface to accommodate joint movement. Articular cartilage, the most familiar hyaline cartilage, forms the smooth gliding surface of joints, such as the knee and the hip, enabling locomotion in animals. Its matrix is composed of proteoglycans, collagen II and glycosaminoglycans (GAGs). This mesh of organic components gives the articular cartilage its unique properties that make it so important in a normal daily life. Further details on this topic can be found elsewhere [59, 61, 64-67]. Hyaline cartilage, including the articular cartilage subtype, is normally the most affected type of tissue among the three mentioned, as a result of trauma and/or degenerative processes. It is also the 
one in which more research is focused on and therefore will be the one highlighted in the present review.

\section{BONE AND CARTILAGE REPAIR MARKET}

Bone and cartilage related diseases are prevalent and their impact is pervasive. Trauma and disease of bone and joints, frequently involving structural damage to both the articular cartilage surface and the subchondral bone, result in severe pain and disability for millions of people worldwide and represent major challenges for the orthopedic surgeons [68]. Moreover, these kinds of diseases drastically affect the psychosocial status of the affected people. Musculoskeletal conditions cause indeed more functional limitation in the adult population than any other group of diseases [69]. In a survey done in Ontario, Canada, musculoskeletal diseases showed to cause $40 \%$ of all chronic conditions, with $54 \%$ accounting for long term disability, and $24 \%$ for all restricted activities [70]. In another survey carried out in Canada, USA and Western Europe, the prevalence of physical disabilities caused by the referred conditions has been estimated at $4-5 \%$ of the adult population [71]. Another example of the impact of these conditions is the number of hip fractures caused by diseases such as osteoporosis or by accident. Worldwide, 1.66 million hip fractures were estimated to occur in 1990 , with the vast majority of them occuring in women. Therefore, as it can be deduced from the numbers presented above, all these conditions represent a major burden for the national healthcare systems and economies. Furthermore, the number of elderly people and the changes in lifestyle throughout the world mean that this situation will only get worst in the forthcoming years. Joint pain is a major cause of disability in middle-aged and older people, and data collected in 2002 numbered the U.S. older population - persons 65 years or older - in 35.6 million, representing $12.3 \%$ of the U.S. population. By 2030 , it is estimated that this number will reach 71.5 million, more than twice the number than in 2000 , constituting $20 \%$ of the total number of people $[72,73]$, which will result in a market evaluated as $\$ 30$ billion by 2010 .

Regarding bone replacement/regeneration, the currently used therapeutical strategies are based on autografts, allografts, demineralized bone matrix and bone substitutes. Autografts and allografts are the most popular methodologies in the field, presenting, however, several disadvantages. Autografts require a second surgical procedure that can lead to infection and chronic pain in the harvest site. Furthermore, it can also cause donor site morbidity, and the amount of biological material available for grafting is not high, limiting in this sense, the type of injuries in which it can be used. Allografts are especially attractive when a larger segment of bone needs to be replaced. It introduces however, the possibility of immune rejection and of pathogen transmission from donor to host, and, although infrequent, infections could occur in the recipient's body due to the transplantation [55].

Regarding cartilage, the current treatments for cartilage associated problems are based on conventional chirurgic methodologies and autologous/allogenous transplants/grafts. As for their counterparts in bone related applications, they present innumerous disadvantages, and it is therefore urgent to find novel therapeutic solutions [55].

\section{ADULT STEM CELLS AND TISSUE ENGIN- EERING IN BONE AND CARTILAGE REGEN- ERATIVE MEDICINE}

Stem cells from different sources are currently under research and observation, and the potential for their application and availability is huge. Even though the concerns and ethical issues on the use of some of these sources are important, some others seem to bring general agreement within the public opinion, such as stem cells collected from a bone marrow biopsy. In fact, ethical issues surrounding human embryonic tissue and a weakening of finances have evolved strategies to slow down, and sent many small companies looking for alliances or mergers. Many investors and large companies that have preferred to avoid the possible controversies of embryonic stem cells are finding alternatives in adult stem cells. The potential use of adult stem cells for therapies may offer substantial opportunities for cell therapy companies looking to capitalize on a market that is currently estimated to exceed $\$ 500$ million in the U.S. and Europe [74].

However, when thinking about possible therapies involving ASCs, a question quickly arises: "What is the best strategy to apply stem cells to bone and cartilage regeneration?" In the text below and in Table $\mathbf{1}$, the readers can find the answer to this question.

A possible therapeutic path could be the administration of drugs/growth factors that would then stimulate the endogenous adult stem cell populations to proliferate and differentiate into the desired phenotypes. Although logical, this particular strategy poses some problems. Firstly, the therapeutic dosages of the growth factors will vary among patients with different diseases. For instance, it has been previously shown that the dose of bone morphogenic protein - 2 (BMP-2) needed for different patients with similar injuries could vary up to 100 fold [75]. Secondly, it has been reported in the literature that the numbers of ASCs decrease with age [76-78] and so it would be less likely that there would be enough number of endogenous ASCs that could actively participate in the regeneration of critical size bone and cartilage injuries. Finally, tissues with low metabolic demands, such as cartilage, have a poor access to ASCs sources, and therefore the growth factor administration would have a small or inexistent effect in the regeneration of that tissue.

Injecting ASCs into the site of injury would be an alternative to the previously referred methodology. This particular strategy would have the advantage of administering the ASCs or differentiated ASCs directly into the injured site, which would probably lead to a faster recovery. However, this therapy is rarely applicable in tissues such as bone and cartilage due to the lack of injury stabilization.

Other approaches using stem cells involve alterations in genetic expression pattern, transfecting genes of interest into the cell nucleus, which demonstrated to possess great potential for regeneration and repair. Both animal and human ASCs in culture have been successfully transduced with exogenous genes using several different vectors without an apparent defect of their stem cell properties [79-81]. 
Table 1. Strategies for the Application of ASCs in Regenerative Medicine (Adapted from [75-81])

\begin{tabular}{|c|c|c|c|}
\hline Stem Cell Source & Strategies Concept & Positive Aspects & Negative Aspects \\
\hline $\begin{array}{l}\text { Embryonic Stem Cells (ES } \\
\text { Cells) }\end{array}$ & $\begin{array}{l}\text { Ethical issues surrounding human } \\
\text { embryonic tissue has caused the } \\
\text { development to slow down }\end{array}$ & & \\
\hline \multirow[t]{4}{*}{ Adult Stem Cells (ASCs) } & $\begin{array}{l}\text { Administration of drugs/growth } \\
\text { factors that stimulate endogenous } \\
\text { ASCs to proliferate and differentiate } \\
\text { into the desired phenotypes }\end{array}$ & $\begin{array}{l}\text { - Enhacement of cell proliferation and } \\
\text { differentiation }\end{array}$ & $\begin{array}{l}\text { - Therapeutic dosages vary among } \\
\text { patients } \\
\text { - Numbers of ASCs decreased with } \\
\text { age [reducing the number of } \\
\text { endogenous ASCs that could actively } \\
\text { participate in the regeneration of } \\
\text { injuries } \\
\text { - Tissues with low metabolic } \\
\text { demands (cartilage) have a reduced } \\
\text { access to ASCs sources having small or } \\
\text { inexistent effect in the regeneration of } \\
\text { that tissue }\end{array}$ \\
\hline & Injecting ASCs into the site of injury & $\begin{array}{l}\text { - Increased recovery time lead to a } \\
\text { faster recovery }\end{array}$ & $\begin{array}{l}\text { - Lack of injury stabilization, } \\
\text { because, in tissues such as bone and } \\
\text { cartilage, in which most of the times the } \\
\text { injuries lead to loss of mechanical } \\
\text { function and inability for load bearing }\end{array}$ \\
\hline & $\begin{array}{l}\text { alterations in genetic expression } \\
\text { pattern, transfecting genes of interest } \\
\text { into the cell nucleus }\end{array}$ & $\begin{array}{c}\text { - Great potential for regeneration and } \\
\text { repair } \\
\text { - Both animal and human ASCs in } \\
\text { culture have been successfully } \\
\text { transduced with exogenous genes using } \\
\text { several different vectors without an } \\
\text { apparent defect of their stem cell } \\
\text { properties }\end{array}$ & $\begin{array}{l}\text { - The use of transfected cells always } \\
\text { poses a problem, due to the possible } \\
\text { health risks that are associated to it }\end{array}$ \\
\hline & $\begin{array}{c}\text { Tissue engineering based strategies } \\
\text { using ASCs }\end{array}$ & $\begin{array}{l}\text { Uses 3D support -a scaffold- that } \\
\text { besides being a substrate for cell culture } \\
\text { will also confer mechanical stability } \\
\text { - Uses ASCs as an adequate cell } \\
\text { source due to their multipotentiality } \\
\text { - In vitro culture that allows an } \\
\text { accurate and adequate effect of several } \\
\text { growth and differentiation factors over } \\
\text { the ASCs } \\
\text { - It uses accurate animal models that } \\
\text { mimic the conditions that are pretended } \\
\text { to regenerate in vivo }\end{array}$ & $\begin{array}{l}\text { Possible immune response, that may } \\
\text { vary with the patient }\end{array}$ \\
\hline
\end{tabular}

Nevertheless, the use of transfected cells always poses a problem due to the possible health risks that are associated to it.

The combination of ASCs with tissue engineering based strategies seemed to be one of the best possible strategies to follow. Tissue Engineering was defined in the early 90's as "an interdisciplinary field of research that applies the principles of engineering and the life sciences towards the development of biological substitutes that restore, maintain, or improve tissue function" [82]. In contrast to classic biomaterials approach, it is based on the understanding of tissue formation and regeneration, and aims to develop new functional tissues, rather than just to implant new spare parts [83].

In this particular field, it is believed that in order to fully develop a tissue equivalent, there are five essential components [82-85]: 1) in order to grow in a 3D manner similar to that found in vivo, cells will need a 3D support -a scaffold- that besides being a substrate for cell culture, will also confer mechanical stability to the construct until the neo-tissue is formed; 2) an adequate cell population to initiate the regenerative process; 3 ) growth and differentiation factors; 4) adequate cell culture methodologies and 5) accurate animal models that mimic the conditions that are pretended to regenerate in vivo. (Fig. (1)) is a representative example of the bone and cartilage tissue engineering strategy followed in our group.

From these five components, a special focus has been put on the first two because: 1) without a scaffold, there is no mechanical stabilization and protection of the injury site and 2) these scaffolds need to be previously seeded with a cell population possessing osteo or chondrogenic potential in order to render them both osteo and chondroinductive behavior. Initially, fully differentiated cells such as osteoblasts and chondrocytes were used for these strategies $[68,86-88]$. However, due to the poor expansion rates or the loss of phenotypic characteristics when expanded in 2D environments, these solutions were far from being ideal. It is in this context that stem cells, and particularly ASCs, have been presented as a possible cell source. However, with the increasing number of reports describing the multipotentiality 


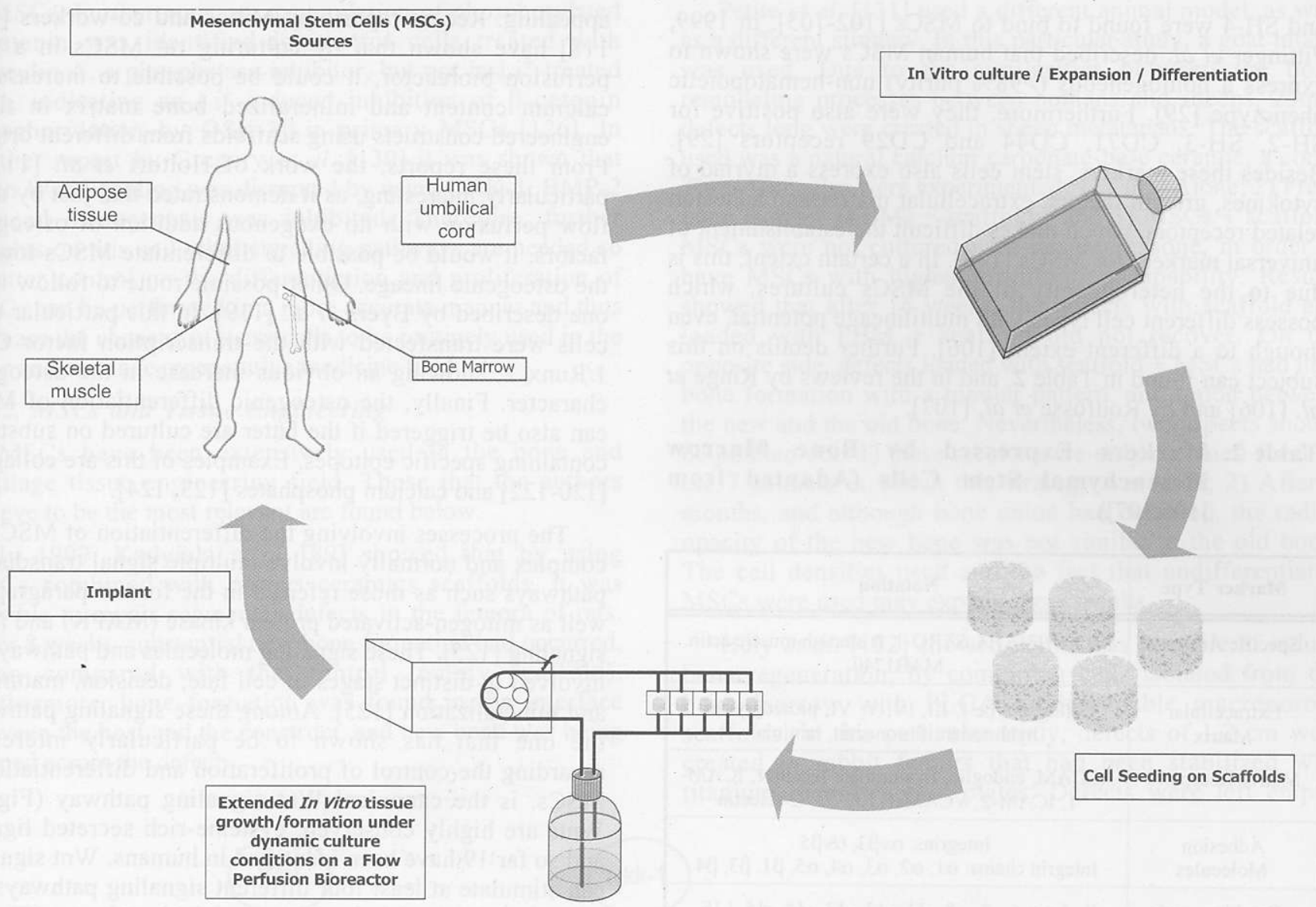

Fig. (1). Representative diagram of the tissue engineering route followed by our group: after isolating stem cells from different origins, these are further expanded in culture, after which they are seeded on 3D scaffolds. In order to increase the differentiation and extracellular matrix apposition rates, the cells/scaffolds constructs are cultured for different periods of time under dynamic conditions. In the end of this culturing period the bone/cartilage tissue engineered construct will ideally be implanted in the affected areas.

of different stem cell sources, it is difficult to say which one is the best and most valuable source for the referred objectives. Therefore, in the next sections, an overview on the potential of, what in the opinion of the authors are the best sources for ASCs for bone and cartilage tissue engineering, will be made.

\section{STEM CELLS FOR BONE AND CARTILAGE TISSUE ENGINEERING}

\subsection{Bone Marrow Derived Mesenchymal Stem Cells (MSCs)}

\subsubsection{Basic Aspects on MSCs}

The non-hematopoietic fraction of bone marrow can be a valid source of stem cells to be used in the bone and cartilage tissue engineering field. It is known that within it, there are different cell populations with varying degrees of differentiation stages, including a population known as Mesenchymal Stem Cells (MSCs), that have been previously shown to be able to develop into distinct terminal and differentiated cells/tissues including bone [29, $89-91]$, cartilage $[29,89,92,93]$, fat $[29,94]$, tendon [95, 96] and muscle [97].
MSCs were first described by Friedenstein and coworkers who demonstrated that fibroblastoid cells could be isolated from single-cell suspensions from rodent bone marrow explants on the basis of their ability to adhere to tissue culture plastic. These cells later showed to be able to rapidly proliferate in vitro and give rise to distinct colonies from single precursors, known as colony-forming units fibroblastic (CFU-F), being at the same time nonphagocytic and clonogenic in nature [98].

Currently, MSCs are isolated through a methodology based on gradient centrifugation described by Haynesworth et al. [99] in the early 1990's. However, it should be referred that even when using this methodology, it is most likely that end cell population will be heterogeneous, possessing cells from progenitor nature besides MSCs [100]. According to the literature, MSCs are present in bone marrow in a quantity of about 1 out of every $10^{5}$ cells, and may be expanded as many as 40 generations while still retaining their multipotent mesenchymal lineage capability, although growth rates are reduced $[34,101]$. This situation could be overcome if there were specific markers that could identify these cells within a heterogeneous cell population. Through the years, some markers have been presented as suitable for MSCs isolation. For instance antibodies SB10, SH-2, SH-3 
and SH-4 were found to bind to MSCs [102-105]. In 1999, Pittinger et al. described that human MSCs were shown to express a homogeneous ( $>98 \%$ purity) non-hematopoietic phenotype [29]. Furthermore, they were also positive for $\mathrm{SH}-2$, SH-3, CD71, CD44 and CD29 receptors [29]. Besides these markers, stem cells also express a myriad of cytokines, growth factors, extracellular matrix and adhesion related receptors, which makes difficult the establishment of universal markers for MSCs [106]. In a certain extent, this is due to the heterogeneity of the MSCs cultures, which possess different cell types with multilineage potential, even though to a different extent [106]. Further details on this subject can found in Table 2, and in the reviews by Ringe et al. [106] and by Roufosse et al. [107].

Table 2. Markers Expressed by Bone Marrow Mesenchymal Stem Cells (Adapted from $[106,107])$

\begin{tabular}{|c|c|}
\hline Marker Type & Notation \\
\hline Specific Antigens & $\begin{array}{l}\mathrm{SH} 2, \mathrm{SH} 3, \mathrm{SH} 4, \mathrm{STRO}-1, \alpha \text { smooth muscle actin, } \\
\text { MAB1740 }\end{array}$ \\
\hline $\begin{array}{l}\text { Extracellular } \\
\text { Matrix }\end{array}$ & $\begin{array}{l}\text { Collagen type I, III, IV, V, VI, proteoglycan, } \\
\text { hyaluronan, fibronectin, laminin }\end{array}$ \\
\hline Matrix Receptors & $\begin{array}{l}\text { ALCAM, endoglin, hyaluronate receptor, ICAM- } \\
\text { 1, ICAM-2, VCAM-1, LFA-3, L-selectin }\end{array}$ \\
\hline $\begin{array}{l}\text { Adhesion } \\
\text { Molecules }\end{array}$ & $\begin{array}{c}\text { Integrins: } \alpha v \beta 3, \alpha v \beta 5 \\
\text { Integrin chains: } \alpha 1, \alpha 2, \alpha 3, \alpha 4, \alpha 5, \beta 1, \beta 3, \beta 4\end{array}$ \\
\hline $\begin{array}{l}\text { Cytokines and } \\
\text { Growth Factors }\end{array}$ & $\begin{array}{c}\text { IL-1 } \alpha,-6,-7,-8,-11,-12,-13,-14,-15, \text { LIF, } \\
\text { SCF, Flt } 3 \text { ligand, GM-CSF, M-CSF }\end{array}$ \\
\hline $\begin{array}{l}\text { Cytokines and } \\
\text { Growth Factors } \\
\text { Receptors }\end{array}$ & $\begin{array}{l}\text { IL-1R, -3R, -4R, -6R, -7R, PDGFR, TNFIR, } \\
\text { TNFIIR, TGF } \beta 1 R \text {, TGF } \beta I I R, \text { IFN } \gamma R \text {, bFGFR, } \\
\text { EGFR, LIFR, G-CSFR, SCFR, transferrin }\end{array}$ \\
\hline
\end{tabular}

The differentiation of MSCs into the osteogenic lineage is a highly programmed process that is essentially best described in vitro. It is known for some years that the synthetic glucocorticoid dexamethasone stimulates and supports osteogenic lineage differentiation [91, 108]. Organic phosphates, such as $\beta$-glycerophosphate, also support osteogenesis by playing a role in the mineralization and modulation of osteoblast activities [109, 110]. Simultaneously, these phosphates have also shown to cause alterations on the production and nuclear export of Cbaf1 (core binding factor alpha 1), which is a well known key regulator transcription factor during osteogenic differentiation [111]. Other known osteogenic factors are ascorbic acid and 1,25-dihydroxyvitamin $\mathrm{D}_{3}[112,113]$. The first one is known to be essential for the production of collagen I [112] on osteogenic cells and the second has previously been shown to increase both alkaline phosphatase activity and in vitro osteocalcin production [113]. Besides these more traditional supplements members of the BMP family, have also been used to induce the osteogenic differentiation in MSCs. For instance, previous work reported by Hanada et al. [114] showed that the addition of BMP-2 alone to MSCs cultures in vitro increased the bone nodule and calcium content of the latter. Other methods, not as conventional as the one described before, have also been used. Among these, the alteration of the culturing conditions through the use of bioreactors has been one of the most appealing. Recent reports by Mikos and co-workers [115118] have shown that by culturing rat MSCs in a flow perfusion bioreactor, it could be possible to increase the calcium content and mineralized bone matrix in tissue engineered constructs using scaffolds from different origins. From these reports, the work of Holtorf et al. [117] is particularly interesting, as it demonstrated that just by using flow perfusion with no exogenous addition of osteogenic factors, it would be possible to differentiate MSCs towards the osteogenic lineage. Other possible route to follow is the one described by Byers et al. [119]. In this particular case, cells were transfected with the transcription factor Cbaf$1 /$ Runx 2 , showing an obvious increase in the osteogenic character. Finally, the osteogenic differentiation of MSCs can also be triggered if the latter are cultured on substrates containing specific epitopes. Examples of this are collagen I [120-122] and calcium phosphates [123, 124].

The processes involving the differentiation of MSCs are complex and normally involve multiple signal transduction pathways such as those referred in the former paragraph as well as mitogen-activated protein kinase (MAPK) and notch signaling [125]. These signaling molecules and pathways are involved in distinct stages of cell fate, decision, maturation and mineralization [125]. Among these signaling pathways, the one that has shown to be particularly interesting regarding the control of proliferation and differentiation of MSCs, is the canonical Wnt signaling pathway (Fig. 2). Wnts are highly conserved, cysteine-rich secreted ligands, and so far 19 have been identified in humans. Wnt signaling can stimulate at least four different signaling pathways, the best characterized being the canonical pathway (Fig. 2), which regulates $\beta$-catenin stability, leading to downstream transcription of target genes. In the absence of a Wnt signal, $\beta$-catenin is phosphorylated by glycogen synthase kinase- $3 \beta$ (GSK-3 $\beta$ ), in association with axin and adenomatous polyposis coli (APC), which targets $\beta$-catenin for ubiquitinylation and subsequent degradation by proteasomes. However, when Wnt ligands bind to Frizzled (Fz) receptors, as well as coreceptors LRP- 5 and LRP-6, the cytoplasmic protein Disheveled (Dvl) is activated. Phosphorylation of $\beta$-catenin by GSK-3 $\beta$ is inhibited by Dvl, causing $\beta$-catenin stabilization and accumulation before translocation to the nucleus, where it binds with the members of the T-cell factor (TCF) and the lymphoid enhancer factor (LEF) transcription factor family, to induce expression of target genes [126]. Several reports have implicated these pathways in bone osteogenic and chondrogenic differentiation of MSCs [125-132], and also with some diseases. de Boer et al. [125, 127] demonstrated that Wnt signalling could either increase proliferation and differentiation. However, these two phenomena were not simultaneous and were dependent on the concentration of Wnts. For high values of Wnt3A, the osteogenic differentiation was stimulated while at low levels, proliferation was favored [125]. A recent paper by Etheridge et al. [126] further revealed that a wide range of components of Wnt signaling was expressed by MSCs, which suggests that this signaling pathway is of fundamental importance in these cells. The presence of $\beta$-catenin in the nucleus of MSCs under control conditions, which increased following Wnt $3 \mathrm{a}$ treatment and $\mathrm{Li}^{+}$application to inhibit GSK-3 $\beta$, provided evidence that canonical Wnt signaling is functional 
in MSCs. Furthermore, an accumulation of phosphorylated $\beta$-catenin was identified in control cells treated with calyculin $\mathrm{A}$, a phosphatase inhibitor, but not in $\mathrm{Li}^{+}$-treated cells, indicating an $\mathrm{Li}^{+}$-induced inhibition of $\beta$-catenin phosphorylation by GSK-3 $\beta$ in primary MSCs [126]. In another report by Gregory et al. [130] it was shown that when Wnt signaling was disrupted by using DKK-1, BMP-2 induced osteogenesis was inhibited. Therefore, further insights on this and other signaling pathways are needed so a better control on the differentiation and proliferation of MSCs can be performed in a more accurate manner and thus increase the chances of these cells to be routinely used in the bone and cartilage regenerative medicine field.

\subsubsection{MSCs and Tissue Engineering}

MSCs have been extensively used in the bone and cartilage tissue engineering field. Those that the authors believe to be the most relevant are found below.

In 1997, Kadyiala et al. [89] showed that by using MSCs combined with porous ceramics scaffolds, it was possible to repair segmental defects in the femora of rats. After 8 weeks, substantial new bone formation had occurred, when compared with the control (empty scaffold). Furthermore, bone formation was found in the interface between the host and the construct, and new bone was being formed across the defect.
Petite et al. [131] used a different animal model, as well as a different strategy. In this particular study, a goat model was used. Due to the similarities between the bone remodeling processes between humans and sheeps, $25 \mathrm{~mm}$ defects long were created in sheep metatarsals. The scaffold used was a natural calcium carbonate-base ceramic, a coral. Three strategies were experimented: 1) Coral Alone; 2) Fresh bone marrow (FBM) + scaffolds; and 3) MSCs + scaffold. MSCs were not cultured with dexamethasone, in order to have MSCs with higher proliferation capability. Results showed that after 16 weeks, the defects with scaffold and loaded with FBM + scaffold did not recover. On the opposite side, defects loaded with scaffold + MSCs had new bone formation with a tubular pattern, and union between the new and the old bone. Nevertheless, two aspects should be pointed out: 1) these results were only obtained for 3 of the 7 animals in which this strategy was used; 2) After 4 months, and although bone union had occurred, the radioopacity of the new bone was not similar to the old bone. The cell densities used and the fact that undifferentiated MSCs were used may explain these results.

Holy et al. [132] showed that it was possible to induce bone regeneration, by combining cells isolated from the bone marrow with PLGA biodegradable macroporous scaffolds. In this particular study, defects of $1.2 \mathrm{~cm}$ were created in rabbit femurs that had been stabilized with titanium reconstruction plates. Defects were left empty,
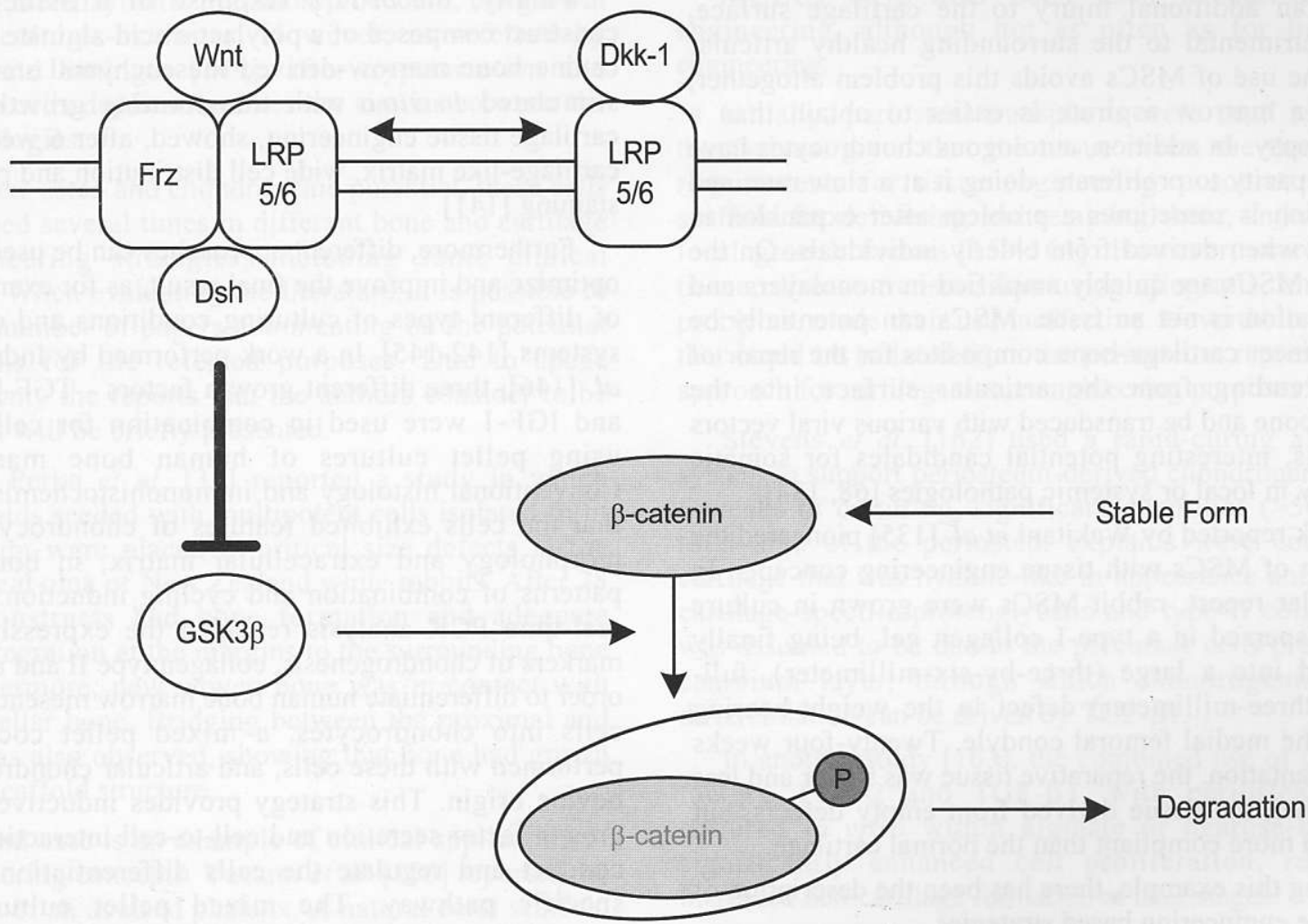

Fig. (2). Scheme of the Canonical Wnt Pathway. The Canonical Wnt Pathway regulates $\beta$-catenin stability, leading to downstream transcription of target genes. In the absence of a Wnt signal, $\beta$-catenin is phosphorylated by glycogen synthase kinase- $3 \beta$ (GSK-3 $\beta$ ), in association with axin and adenomatous polyposis coli (APC), which targets $\beta$-catenin for ubiquitinylation and subsequent degradation by proteasomes. However, when Wnt ligands bind to Frizzled (Fz) receptors, as well as coreceptors LRP- 5 and LRP-6, the cytoplasmic protein Disheveled (Dvl) is activated. Phosphorylation of $\beta$-catenin by GSK-3 $\beta$ is inhibited by Dvl, causing $\beta$-catenin stabilization and accumulation, before translocation to the nucleus, where it binds with members of the T-cell factor (TCF) and lymphoid enhancer factor (LEF) transcription factor family, to induce expression of target genes. (Adapted from 130). 
filled with a scaffold, or filled with a tissue engineering construct seeded with autologous bone marrow cells that had been maintained in culture for 14 days under osteogenic conditions, prior to the surgery. Results revealed that significantly more new bones had formed in the tissue engineered construct group right after 2 weeks. After 6 weeks, x-rays indicated that the defects in these groups showed radio-opacity throughout the entirety of the segmental defects, while only limited radio-opacity was observed in empty and scaffold filled.

Quarto et al. [133] reported a strategy based on multipotent cells isolated from the bone marrow for the recovery of large bone defects (up to $7 \mathrm{~cm}$ ) in three different patients. In this study, the MSCs were loaded into macroporous HA scaffolds, with these having the exact shape of the place where they were going to be implanted. It was not referred whether the cells had been primarily differentiated towards the osteogenic lineage. Two months after the surgeries, radiographs and CT scans showed abundant callus formation along the implants and good integration at the interfaces with the host bone by the second month after the surgery. According to the authors, the healing of the defects was superior when compared to the traditional bone graft approach.

MSCs potential for cartilage regeneration and repair is also quite interesting. Whereas a cartilage biopsy from the joint to obtain differentiated chondrocytes for cell therapy represents an additional injury to the cartilage surface, possibly detrimental to the surrounding healthy articular cartilage, the use of MSCs avoids this problem altogether, given that a marrow aspirate is easier to obtain than a cartilage biopsy. In addition, autologous chondrocytes have a limited capacity to proliferate, doing it at a slow rate, and differentiation is sometimes a problem after expansion in monolayers when derived from elderly individuals. On the other hand, MSCs are quickly amplified in monolayers and dedifferentiation is not an issue. MSCs can potentially be used to engineer cartilage-bone composites for the repair of defects extending from the articular surface into the underlying bone and be transduced with various viral vectors and are thus, interesting potential candidates for somatic gene therapy in local or systemic pathologies [68, 134].

The work reported by Wakitani et al. [135] pioneered the combination of MSCs with tissue engineering concepts. In this particular report, rabbit MSCs were grown in culture and then dispersed in a type-I collagen gel, being finally transplanted into a large (three-by-six-millimeter), fullthickness (three-millimeter) defect in the weight-bearing surface of the medial femoral condyle. Twenty-four weeks after transplantation, the reparative tissue was stiffer and less compliant than the tissue derived from empty defects, but less stiff and more compliant than the normal cartilage.

Following this example, there has been the description of several tissue engineering based strategies.

For instance, a highly porous silk scaffold was combined with human MSCs under a specific cocktail of growth factors, with the purpose of developing an in vitro cartilage tissue engineering approach. After 3 weeks of cultivation, the spatial cell arrangement and the collagen type-II distribution in the MSCs-silk scaffold constructs resembled those of native articular cartilage tissue [136].
The ability of an electrospunned nanofibrous scaffold made of poly( $\varepsilon$-caprolactone) to support in vitro chondrogenesis of MSCs derived from human bone marrow over a 21-day culture period, was also assessed. MSCs cultured in the presence of TGF- $\beta 1$ differentiated to a chondrocytic phenotype, as evidenced by chondrocytespecific gene expression and synthesis of cartilage-associated extracellular matrix (ECM) proteins [137].

In another approach [138], human mesenchymal stem cells were cultured in vitro in a cobweb-like biodegradable polymer scaffold: a poly(DL-lactic-co-glycolic acid)-collagen hybrid mesh in serum-free DMEM containing TGF- $\beta 3$ for 1-10 weeks. After 4 weeks, the matrices were positively stained by safranin-O and toluidine blue, as well collagen type II and proteoglycan were detected around the cells.

Three-dimensional PLGA scaffolds seeded with cultured rabbit MSCs were also transplanted into large defects in rabbit knees and analyzed histologically at 4 and 12 weeks after the operation. A hyaline-like cartilage structure was shown at 12 weeks after the transplantation [139]

In another study, hyaluronan-based scaffolds seeded with mesenchymal progenitors were used and implanted in New Zealand white rabbits. Four months after transplantation, there was histological evidence that lesions filled with the biomaterial achieved a faster and better healing compared to empty controls [140].

Finally, the in vivo response of a tissue-engineered construct composed of a polylactic acid-alginate seeded with canine bone marrow-derived mesenchymal stem cells and stimulated in vitro with transforming growth factor for cartilage tissue engineering, showed, after 6 weeks, to have cartilage-like matrix, wide cell distribution and proteoglycan staining [141].

Furthermore, different approaches can be used in order to optimize and improve the final result, as for example the use of different types of culturing conditions and co-culturing systems [142-145]. In a work performed by Indrawattana et al. [146], three different growth factors - TGF- $\beta 3$, BMP-6, and IGF-1 were used in combination for cell induction, using pellet cultures of human bone marrow cells. Conventional histology and immunohistochemistry showed that the cells exhibited features of chondrocytes in their morphology and extracellular matrix, in both inducing patterns of combination and cycling induction. Moreove:, real-time PCR analysis revealed the expression of gene markers of chondrogenesis, collagen type II and aggrecan. In order to differentiate human bone marrow mesenchymal stem cells into chondrocytes, a mixed pellet coculture was performed with these cells, and articular chondrocytes from bovine origin. This strategy provides inductive signals by growth factor secretion and cell-to-cell interactions that can conduct and regulate the cells differentiation towards a specific pathway. The mixed pellet culture showed upregulation of cell proliferation, cartilaginous extracellular matrix production and type II collagen gene expression [147].

\subsection{Mesenchymal Cambial Layer Cells}

The periosteum is a bilayered tissue membrane that is attached to bone cortex [148]. In general, periosteal activity 
influences osteogenesis and, more specifically, the cortical blood supply [149]. It is believed that cells from the periosteum cambial layer may be the first contributors, together with osteoblasts, in driving the cell differentiation process of bone repair, with the development of the initial fracture callus and subsequent remodeling $[149,150]$. In this sense, periosteum can be considered as an osteoprogenitor cell-containing bone envelope, which can be activated following situations of trauma [149]. A number of studies [31, 151-155] have also shown that the periosteum cambium layer also possesses chondroprogenitor cells that can also promote new cartilage. Due to these observations, periosteal cells have been named as multipotent mesodermal cells, osteoprogenitor cells precursor cells, mesenchymal stem cells, and mesenchymal precursor cells. However, and as accurately referred by Hutmacher and Sittinger [149], up to now, the cells from the cambial layer have not fully shown to possess the full characteristic of a stem cell, and therefore in the present paper, we will use the same terminology used by the above referred authors, that is the mesenchymal cambial layer cells (MCLCs).

The isolation of MCLCs is preceded by the collection of a biopsy from the periosteum, which is then further diced into $10 \times 10 \mathrm{~mm}$ pieces. At this time, two culturing strategies can be adopted: 1) spontaneous outgrowth from small specimens, also known as explant culture and 2) enzymatic digestion procedure. Both methods are effective, although as expectable in the enzymatic digestion procedure, the growth of primary cultures is faster. However, as referred by Hutmacher and Sittinger [149], after trypsinization and replating, the cells duplication rates are similar between the two methodologies.

Due to their osteo and chondrogenic potential, these cells have been used several times in different bone and cartilage tissue engineering strategies, including some clinical applications. When evaluating the literature, it is possible to find a large number of papers commenting on the potential of these cells for the referred purposes. Due to space constraints, only the reports that the authors consider to be most relevant will be briefly presented.

In 2000, Perka et al. [31] reported a study in which PLGA scaffolds seeded with multipotent cells isolated from the periosteum were placed in critical size defects in the metadiaphyseal ulna of New Zealand white rabbits. After 28 days, the constructs had bone formation and adequate transplant integration at the margins to the surrounding bone tissue. Furthermore, new woven bone was in contact with the host lamellar bone. Bridging between the proximal and distal end was also observed, showing that bone had grown through the scaffold structure.

The second case is an example of clinical application of tissue engineering concepts. Vacanti et al. [156] reported the replacements of an avulsed phalanx. A natural coral scaffold (500 pore Pro-Osteon, Interpore International) was filled with periostal; cells previously isolated were implanted in the affected area. Twenty-eight months after the implantation, the patient had a thumb of normal length and strength, with some sensation. Examination of the implant revealed the latter was vascularized, non-fragmented and well incorporated into the surrounding tissue. Furthermore, new lamellar bone was found to be in contact with the coral scaffold. However, histomorphometric analysis showed that lamellar bone made only $5 \%$ of the implant, with the rest being composed of coral, blood vessels and soft tissue.

Shantz et al. [157] reported a study on the possible induction of ectopic bone formation by a tissue engineering construct made of MCLCs and a novel scaffold architecture whose mechanical properties were in the range of cancellous bone. The cell-scaffold constructs were cultured for a period of 3 weeks prior to implantation into balb $\mathrm{C}$ nude mice. The implants were analyzed 6 and 17 weeks postoperatively. In vivo, endochondral bone formation with osteoid production was detectable via von Kossa and osteocalcin staining after 6 and 17 weeks.

Finally, the work from Schmelzeisen et al. [158], also shows the potential of these progenitor cells to be used in the bone tissue engineering field and in the clinics. The objective of this work was to conduct a bone augmentation in maxilla before dental implant placement could occur. In this case, MCLCs were combined with fibrin glue and a textile scaffold, and maintained in vitro under osteogenic conditions for 1 week. Four months later, biopsies were collected and histological analysis revealed that trabecular bone containing viable osteocytes was present. This methodology led to the development of the first commercialized tissue-engineered bone graft (bioseed B; Biotisse technologies, Freiburg, Germany).

MCLCs have also been used in cartilage tissue engineering, although not as often as for bone tissue engineering.

Initially, periosteal transplants were used as scaffolds themselves, given that the tissue meets the three primary requirements for tissue engineering: a source of cells, a scaffold for delivering and retaining them, and a source of local growth factors [159-161]. However, scarcity of the tissue, disease transmission using allografts, among other problems, made their use ineffective. Nevertheless, the cells that could be isolated from the periosteum represent a valid approach for cartilage tissue engineering purposes.

Stevens et al. [162] used a rapid-curing alginate gel system to support periosteum-derived chondrogenesis. After 6 weeks of culturing, significant quantities $(>50 \%)$ of the total area of the periosteal explants were composed of cartilage that was hyaline-like in appearance and contained cartilage-specific proteoglycans and type-II collagen. This was assumed to be due to the precursor cells present in the cambium layer, through which chondrogenic terminal differentiation can be driven by TGF- $\beta 1$.

In another study [163], the combined use of two growth factors, FGF-2 and TGF- $\beta 1$, with periosteal explants cultured in vitro within alginate or agarose-based gels, significantly enhanced cell proliferation, resulting in increased neo-cartilage formation at later stages.

From the examples referred above, it is clear that MCLCs have indeed the potential to be used in cartilage and bone reparative medicine, namely for the latter. However, when comparing to the most common source for these purposes, MSCs, their potential is not so broad, and their lifespan might be shorter than the one for MSCs. Furthermore, it is also not known if these cells have indeed a true "stem" character or are just only progenitors. Finally, 
while for the MSCs, it has been suggested that they may have an immunoprivileged character that is not known for the periosteal cells.

\subsection{Adipose Tissue Derived Adult Stem Cells}

An ideal source of autologous stem cells should be both easy to obtain, result in minimal patient suffering, and yet be capable of yielding cell numbers substantial enough to prevent extensive expansion in culture [164, 165]. Adipose tissue may represent such a source. Adipose tissue, like bone marrow, is derived from the embryonic mesoderm [166]. These similarities, together with the identification of MSCs in several tissues, make plausible the concept that a stem cell population can be isolated from human adipose tissue and used as a source of autologous stem cells for clinical proposes [167, 168].

The presence of an adult stem cell population within fat tissue, know as Adipose Tissue Derived Adult Stem Cells (ADASCs) was firstly described by Zuk et al. [34]. According to these authors, ADASCs isolation begins with a liposuction to collect the fat tissue that is then enzymatically digested with collagenase to release the cells from the extracellular matrix (ECM). The cells are then collected by differential centrifugation separating the mature adipocytes that float from the pellet that contains the desired stem cells population $[169,170]$.

After in vitro expansion, ADASCs acquire a fibroblast like morphology, similar to the one observed for MSCs [34]. Furthermore, and like MSCs, they also express a series of cell-specific proteins and CD markers, described in detail in Table 3 , showing to be phenotypically similar to MSCs obtained from bone marrow $[169,171]$. Furthermore, they have also shown to be differentiated towards the adipogenic, osteogenic and chondrogenic lineages [34, 164, 167, 170 $171,173-176]$, revealing in this sense, more characteristics of a stem cell behaviour.

ADASCc osteogenic differentiation is achieved in the presence of ascorbic acid, $\beta$-glycerophosphate, dexamethasone and 1,25 vitamin D3 in Dulbecco's Modified Eagle Medium (DMEM) with 10\% Fetal Bovine Serum (FBS) and 1\% antibiotic/antimycotic over 3-4 weeks [167, $170,176]$. Osteogenic differentiation can be assessed by the identification of osteoblast phenotype markers such as ALP activity, extracellular matrix production by the presence of bone matrix proteins like osteopontin (OP), osteonectin (ON), bone sialoprotein-2 (BSP-2), osteocalcin (OC), and collagen type I among others, and by the calcification and formation of bone nodules [173, 177].

The potential of these cells to be used for bone tissue engineering was shown by Hicok and colleagues, which demonstrated the ability of ADASCs to form bone in vivo [174]. They isolated ADASCs from liposuction human waste, which were then further expanded in vitro. When seeded on hydroxyapatite/tricalcium-phosphate and subcutaneously implanted into SCID mice for 6 weeks, they showed to be capable of causing the formation of osteoids in $80 \%$ of the implant. They also showed that the osteoids were really formed by the human ADASCs, by identifying immunologically human cells contained in the newly formed osteoid [174]

In a very interesting report, Cowan and colleagues [178] assessed the in vivo osteogenic potential of ADASCs to repair a critical-size mouse calvarial bone defect. ADASCs were seeded on apatite coated scaffolds made of PLGA and after X-ray analysis, histology and live micromolecular imaging, it was possible to observe significant bone formation and defect bridging after 2 and 12 weeks

Table 3. Adipose-Derived Adult Stem Cells Surface Proteins Positively Identified (Adapted from [168, 170, 172])

\begin{tabular}{|c|c|c|}
\hline Adhesion molecules & $\begin{array}{c}\text { Tetraspan Protein } \\
\text { Integrins bl } \\
\text { Integrins a4 } \\
\text { Entercellular Adhesion Molecule } 1 \\
\text { Endoglin } \\
\text { Vascular Cell Adhesion Molecule } \\
\text { Activated Lymphocyte Cell Adhesion Molecule }\end{array}$ & $\begin{array}{c}\text { CD9 } \\
\text { CD29 } \\
\text { CD49d } \\
\text { CD54 (ICAM-1) } \\
\text { CD105 } \\
\text { CD106 (VCAM) } \\
\text { CD166 (ALCAM) } \\
\end{array}$ \\
\hline Receptor molecules & $\begin{array}{c}\text { Hyaluronate receptors } \\
\text { Transferrin receptors }\end{array}$ & $\begin{array}{l}\text { CD44 } \\
\text { CD71 } \\
\end{array}$ \\
\hline Surface enzymes & $\begin{array}{l}\text { Endopeptidase } \\
\text { leukemia antigen } \\
\text { Aminopeptidase } \\
\text { Ecto 5' nucleotidase }\end{array}$ & $\begin{array}{l}\text { CD10 } \\
\text { CALLA } \\
\text { CD13 } \\
\text { CD73 } \\
\end{array}$ \\
\hline Extracellular matrix proteins and glycoproteins & $\begin{array}{c}\text { Collagen I } \\
\text { Collagen III } \\
\text { Osteopontin } \\
\text { Osteonectin } \\
\text { Thy-1 } \\
\text { MUC-18 } \\
\end{array}$ & $\begin{array}{c}- \\
- \\
- \\
- \\
\text { CD90 } \\
\text { CD146 }\end{array}$ \\
\hline Skeletal proteins & $\begin{array}{l}\text { Intracellular alpha smooth muscle actin } \\
\text { Vimentin }\end{array}$ & - \\
\hline Complement regulatory proteins & $\begin{array}{c}\text { Decay Accelerating Factor } \\
\text { Complement Protectin }\end{array}$ & $\begin{array}{l}\text { CD55 } \\
\text { CD59 } \\
\end{array}$ \\
\hline Histocompatibility & A,B, $\mathrm{C}($ Class I $)$ & - \\
\hline Hematopoietic & - & CD34 \\
\hline
\end{tabular}


respectively. Weeks and to completely bony bridge the defect after 12 weeks.

These facts demonstrate that ADASCs can be used as a new cell source for bone tissue engineering, revealing to be a very good alternative compared to other cell sources, not only because of its capacity for bone repair and regeneration but also for its availability, as adipose tissue can be obtained from the patient with a minimally invasive procedure of liposuction, and also yield a large number of autologous cells [177].

ADASCs chondrogenic differentiation can be induced in the presence of insulin, TGF- $\beta 1$, ascorbate-2-phosphate in DMEM with $1 \% \mathrm{FBS}$ and $1 \%$ antibiotic/antimycotic [170] In this process, the chondrogenic factors are not sufficient to induce the ADASCs into the chondrogenic pathway, and therefore they must be cultured in high-density micro mass (pellet culture) $[164,167]$. This fact is probably related with the analogous events that occur in vivo where the chondrocytes exist in an almost anaerobic environment and entrapped on a tight matrix with close connection between the cells. The differentiation can be verified by the presence of chondrocyte-phenotypic markers such as aggrecan, collagen type II, Sox -9 , collagen type 6 , collagen type 10 , and collagen type 9 .

Awad and colleagues [175] compared the chondrogenic differentiation of ADASCs seeded in alginate and agarose hydrogels, and porous gelatin scaffolds, and the functional properties of tissue engineered cartilage constructs under chondrogenic media. This chondrogenic media that was supplemented with TGF- $\beta 1$ showed to significantly increase the protein and proteoglycan synthesis as well as the content of DNA, sulfated glycosaminoglycans and hydroxyproline. They also verified, under chondrogenic culture conditions, an increase in $86 \%$ and $160 \%$ in the equilibrium compressive and shear moduli of the gelatin scaffolds and also in the agarose scaffolds. The authors have also found that the increases in the shear moduli were significantly associated with increases in S-GAG content and with the interaction between S-GAG and hydroxyproline.

Betre and colleagues [176] have achieved the chondrogenic differentiation of ADASCs only by its encapsulation on a elastin-like polypeptide hydrogel with the aim to avoid the use of all the current chondrogenic agents.

These facts clearly demonstrate the versatility of human ADASCs to go under chondrogenic differentiation on different materials/scaffolds, allowing the manipulating of the composition of these tissue engineered constructs in order to obtain the more adequate and desired mechanical properties [175].

\subsection{Skeletal Muscle Derived Stem Cells}

During vertebrate embryogenesis, mesodermal progenitors give rise to distinct terminally differentiated cell lineages, including skeletal myocytes, osteocytes, chondrocytes and adipocytes, as a consequence of the action of different stimuli delivered by the surrounding environment [32]. In fact, most of the tissues with mesodermal origin have shown to possess stem cells. Therefore, due its mesodermal character, it is plausible to accept that the adult skeletal muscle possesses a population of stem cells that do not only play a role in the maintenance of the musculature, but at the same time, show a multipotential character being capable of differentiating into different cell lineages of mesenchymal origin

Up to know, two muscle stem cell populations with a possible mesenchymal character have been described: satellite cells and muscle derived stem cells (MDSCs). However, it should be pointed out that these nomenclatures are not standardized within the field. For instance, in a paper by Wada et al. [179], satellite cells are described as skeletal muscle stem cells, while in the review by O'Brien et al [180], there is a clear distinction between the these two cell populations. As the authors of the present paper tend to agree with what was presented by the latter, in the present review, the above referred cell populations will be discussed as different ones.

\subsubsection{Muscle Satellite Cells}

Muscle satellite cells are found adjacent to skeletal muscle myofibers and lie underneath the basal lamina [180]. They were first identified in 1961 by Katz [181] and Mauro [182] and are thought to be the main source of new myonuclei in postnatal muscle. In normal muscle, satellite cells are mitotically quiescent, becoming activated to divide in response to signals released following damage or in response to increase workload [183]. After division, satellite cell progeny, known as myoblasts, undergo terminal differentiation and become incorporated in mature muscle fibers as post-mitotic myonuclei [183]. In this sense, satellite cells provide a reserve capacity to replace differentiated, post-mitotic cells required for the functions of the skeletal muscle. Satellite cells commonly express myogenic markers when they differentiate [180]. When initiating division, satellite cells express either myf- 5 or Myo-D [180]. Furthermore, this cell population has also shown to express a number of other proteins including desmin, c-met, M-cadherin, Pax7 and Bcl-2. Satellite cells have for long been considered as precursor rather than stem cells. However, in 2001, Asakura and co-workers [32] reported that satellite cells could possess a stem cell character. In that report it was revealed that upon stimulation with BMPs, it was possible to obtain cells with osteogenic character expressing both alkaline phosphatase (ALP) and osteocalcin, which is known to be specific for osteoblasts [32]. Furthermore, these cells were also able to differentiate into the myogenic and adipogenic lineages [32]. However, it should be noticed that in this report, no results regarding clonality or self-renewal were shown, and so the true "stem" character of these cells cannot be fully evaluated or screened. A similar behavior by muscle satellite cells was revealed in another study by Wada et al. [179]. In this particular report, a clone of unmanipulated myogenic cells derived from a single mouse muscle satellite cell was used. As for the previous study, this clone of cells managed to differentiate towards the osteogenic lineage when stimulated by BMP-2, showing Cbaf-1/Runx2 expression and bone nodule formation when $\beta$-glycerophosphate was added [179]. This was a clear evidence of the osteogenic potential of these cells. In both cases, the differentiation path is described as having a myogenic progenitor that gives origin to the cells with osteogenic profile $[32,179]$. Therefore, a question 
arises, is this myogenic cell a mesenchymal progenitor that is able to differentiate into the different mesenchymal lineages or, does this mesenchymal cell "transdifferentiate" into other lineages? Up to now there is no clear answer to this question, and its solution could indeed enhance the potential of these cells for uses within the bone and cartilage regenerative medicine.

\subsubsection{Muscle Derived Stem Cells}

Muscle derived stem cells (MDSCs) are mostly distinct from satellite cells, and are believed to be located either in the connective tissue regions of the skeletal muscle or most likely in the vasculature, more specifically, the capillaries surrounding the myofibers [33, 184, 185]. MDSCs can be separated into two main subpopulations based on their relationship with hematopoietic stem cells: CD45+ MDSCs and CD45-MDSCs. The latter cell population is the one of interest for bone and cartilage regeneration. Previous work by McKirmey-Freeman et al. [186] and Adachi [187] has shown that these cells have both chondro and osteogenic potential. In culture, MDSCs commonly express desmin and Myo D and stem cell markers such as CD34, sca-1 and Bcl$2[33,185,188,189]$. The most common method to isolate MDSCs is through a methodology named pre-plating technique, firstly reported by Qu et al. in 1998 [190]. This pre-platting technique passages unsettled floating cells onto new tissue culture plates first at short intervals (1-2 hours), to eliminate contaminating fibroblasts, followed by longer incubations of 24 hours for approximately 6 days [ 189 , 190]. This method enriches for small cells, which are referred to as PP6 cells [180]. Like satellite cells, MDSCs also differentiate towards the osteogenic lineage when exposed to BMPs 2 and 4 [33]. However, the most common strategy used to differentiate these cells is the transfection with viral vectors expressing BMP-2 and 4 . Several authors have described positive results regarding the regeneration of critical size bone defects by using the above referred strategy [191-193].

Muscle derived stem cells have also shown to have chondrogenic potential, although this particular field has not been so thoroughly explored when compared to bone. In fact, few studies exist on the use of muscle-derived cells for the treatment of articular cartilage defects. Adachi et al. [187] evaluated the effectiveness of transplanted allogeneic muscle derived cells embedded in collagen gels for treating full thickness articular cartilage defects. The results suggested that the allogeneic muscle derived cells could be used for repairing full thickness articular cartilage defects, with the cells being suitable not only as a cell source but also as a gene delivery vehicle.

\subsection{Umbilical Cord Stem/Progenitor Cells}

The umbilical cord can also be another source of adult stem cells with osteo and chondrogenic potential. Over other sources of stem cells, umbilical cord presents a number of advantages in cell procurement, such as vast abundance (depending on the origin), lack of donor attrition and low risk of transmission of herpes family viruses [194]. From the literature and up to know, three possible sources for adult stem cells with putative mesenchymal character have been described [38-40, 194-200]: Cord blood, luminal vein and Wharton Jelly.

\subsubsection{Cord Blood}

In 2000, Erices et al. [38] reported the presence of a population of mesenchymal progenitors present in the cord blood. In this report it was described that from approximately only $25 \%$ of the cords, it was possible to isolate a population with mesenchymal character, denominated by the authors as mesenchymal progenitor cells (MPCs). When in culture, they displayed a fibroblast-like morphology, similar to the one reported for bone marrow MSCs, expressing at the same time several MSCs related antigens, such as $\mathrm{SH} 2$, SH3, SH4, ASMA, MAB 1470, CD13, CD29 and CD49e [38]. Furthermore, it was also revealed that when stimulated under proper conditions, these cells could undergo not only adipogenic differentiation, but could also be directed toward the osteogenic lineage, showing bone nodule formation and ALP activity. Although interesting, this paper ends up missing in some parts, namely those related with the selfrenewal of the described cell population, and the fact that is not known if the terminally differentiated cells were obtained from a single clone. Furthermore there was no data regarding the in vivo functionality of these cells. Some of these topics were later addressed in a paper by Lee et al. [195], in which through combining a technique based on limiting diluting assays and immunoselection, the authors managed to expand single cell derived, clonally expanded adult stem cells with mesenchymal character. In fact, the latter when put in contact with the traditional differentiation factors were able to differentiate into the osteogenic, chondrogenic and adipogenic lineages showing therefore a true mesenchymal nature. The osteogenic differentiation was supported by the deposition of mineralized ECM (i.e. bone nodules), and the expression of genes related with osteogenic differentiation such as osteopontin, osteocalcin and collagen I, while the chondrogenic differentiation was shown by the expression of typical markers of chondrogenesis, such as collagen II. This paper was by then a clear demonstration that cord blood had indeed an adult stem cell population with mesenchymal character. However, the reports from Wexler et al. [201], Mareschi et al. [202] and Yu et al. [203] contradicted the earlier reports, as they failed to show the presence of MSCs in the cord blood. These intriguing facts are yet to be explained and the reasons for them unknown, but as stated by Gang et al. [194], it is most likely that the frequency of hMSCs in the neonatal circulating blood system is so low that their survival/death is largely affected by minute differences in culture conditions between different laboratories. This fact was demonstrated in a recent paper by Tondreau et al. [196]. According to the authors, the simple incubation during the first 48 hours of stem cells isolated from the umbilical cord in conditioned medium obtained from MSCs cultures increased their proliferation. Still in this report, a novel approach to obtain a richer fraction of MSCs from the umbilical cord was followed. By selecting $\mathrm{CD}_{133^{+}}$cells from the original heterogeneous cell population, it was possible to obtain a higher fraction of MSCs with higher proliferating capability, disclosing at the same time OCT-4 expression, and showing both osteo and chondrogenic differentiation potential. Finally, and regarding the possible use of MSCs present in the cord blood, two reports are particularly interesting and worth to mention. The 
first is the one authored by Rosada et al. [197], which makes a direct comparison between bone marrow MSCs and cord blood MSCs, including an in vivo assay in which the cells were previously mixed with hydroxylapatite/tricalcium phosphate powder and then subcutaneously implanted in immunocompromised mice. Interestingly, it was observed that after 8 weeks, the HA/TCP+cells construct formed a mixture mixture of stroma like tissues that enclose hematopoietic cells and adipocytes. It was also possible to observe the presence of the bone at the interface of the HA/TCP powder and the surrounding tissues. However, the amount of bone formed was of lower magnitude when directly compared with those implants seeded with MSCs. The second one is the paper published by Kogler et al. [198], which besides describing a new somatic stem cell from placental cord blood, also reports on the in vivo functionality of these cells when previously seeded in a $3 \mathrm{D}$ scaffold and further implanted in a mice, either subcutaneously or in femoral defects. After 3 weeks, it was possible to observe a cartilage tissue-like formation on the subcutaneous model. Regarding bone regeneration, the results showed that after 4 weeks, the human cells were still alive within the bone defect. Furthermore, it was also shown that bony integration was established in the form of cancellous bone, and after 12 weeks, bony reconstitution was observed. These experiments indeed showed the potential of these cells to be used within the field of bone and cartilage tissue engineering.

\subsubsection{Vein}

Another possible source of mesenchymal progenitors is the cord itself, and up to now, different locations within it have apparently shown to possess mesenchymal progenitors. One of such locations is the umbilical as the umbilical cord vein $[39,199]$. According to the methods described, these cells are isolated by digesting the inner wall of the vein, exposing the latter to a collagenase solution. In both cases, the initial cultures were heterogeneous, as expected, possessing both endothelial cells and fibroblast like cells, with an MSC-like morphology. However, and according to the results described by Kim et al. [199], from only $6 \%$ of the cords, it was possible to obtain these MSC like cells. It should be noticed that it was not referred by the authors the actual number of cells that were present in the heterogeneous cultures isolated from the umbilical cord vein. Therefore, it is not possible to estimate their approximate number in the cord. Nevertheless, in both studies, the fibroblastic cells were negative for endothelial markers such as Von Willenbranf factor (vWF) and PECAM-1. As in other cases, when exposed to osteogenic conditions, these cells revealed typical signs of osteogenic differentiation. While in case of the work reported by Romanov et al. [48], this was only shown by alkaline phosphatase activity, in the case of Kim et al. [199], it was possible to observe the deposition of a mineralized extracellular matrix and cells showed the expression of Runx 2 and osteopontin, both of them being markers of osteogenic differentiation. These results are interesting, but deeper studies need to be conducted, namely regarding their number, clonality and especially in vivo functionality assays that will allow us to conclude about the real potential of umbilical cord vein mesenchymal progenitor/stem cells to be used in the field of bone and cartilage regenerative medicine.

\subsubsection{Wharton Jelly}

Finally, the Wharton jelly, the primitive connective tissue of the umbilical cord has also been described as a potential source of progenitors/stem cells with osteogenic and chondrogenic potential. The rationale for this hypothesis is well explained in the report by Sarugaser et al. [40]. According to the report, the umbilical cord is embryologically derived at day 26 of gestation, and it grows to form a $30-50 \mathrm{~cm}$ long helical structure at birth. Given the expansion during the 40 weeks of gestation, the authors accurately hypothesized that there must be a mesenchymal precursor population within the umbilical cord that gives rise to the Wharton jelly connective tissue. According to the authors, it would be most likely that these cells are located closer to the vasculature, as they would be closer to a source of oxygen and nutrients. In this report, the authors described a novel cell population denominated as Human Umbilical Cord Perivascular Cells (HUCPVCs), which are isolated after submitting the cord blood vessels (arteries and veins) and the surrounding Wharton jelly to an enzymatic digestion for periods between 18-24 hours. According to what was described, each cell harvest gave rise to around $2-5 \times 10^{6}$ cells. Upon culture, these cells displayed a fibroblast-like morphology, expressing at the same $\alpha$-actin, desmin, vimentin, 3G5 (a pericyte marker), and typical mesenchymal stem cells markers such as $\mathrm{SH} 2, \mathrm{SH} 3$ and $\mathrm{CD} 144$, and a colony-forming unit fibroblast frequency (CFU-F) of 1:333. Simultaneously, these cells also had high expansion rates producing over $10^{10}$ cells within 30 days of culture. It was also demonstrated that these HUCPVCs had a subpopulation that exhibited a functional osteogenic phenotype and elaborated bone nodules, with the frequency of the appearance of the latter being higher when osteogenic supplements were added to the culture medium. Finally, it was revealed that HUCPV cells presented a $20 \%$ subpopulation of cells that present neither class I nor class II cell-surface major histocompatibility complexes $\left(\mathrm{MHC}^{-/-}\right)$, which increase to $95 \%$ after 5 passages. This last property is particularly interesting as indicated that the cell population under study might be used for allogeneic transplantation. Another paper on the putative presence of mesenchymal/progenitor stem cells on the Wharton jelly was published by Wang et al. [200]. In this case, the cells were obtained by scrapping of the mesenchymal tissue from the Wharton jelly, followed by a series of enzymatic digestions. In this sense, it is not possible to know whether the authors dealt with the same population described by Sarugaser et al. or not. As for the former, the cells described in the paper by Wang et al. were also positive for mesenchymal markers such as $\mathrm{SH} 2$ and $\mathrm{SH} 3$. However, it is not described if there was the presence of a subpopulation capable of forming bone nodules without the addition of osteogenic supplements, or with the same MHC characteristic of that one reported by Sarugaser et al. Neverthless, the authors show that upon stimulation with osteogenic supplements, it was possible to observe a cell population with high indexes of ALP activity as well as the expression of osteopontin, which is normally related with the elaboration of the initial bone extracellular matrix, and therefore indicate that these cells were in the initial stages of osteogenic differentiation. This same cell population also showed to possess chondrogenic potential. After exposure to chondrogenic differentiation agents, in a 
pellet culture system, cells expressed collagen II within a matrix typical of cartilage cartilage ECM elaboration.

Overall, it can be said that the various cell populations isolated from the different areas of the umbilical cord show an interesting potential for application within the bone and cartilage tissue engineering field. However, when directly compared with MSCs from the bone marrow, our knowledge about cord cells is still scarce, and important in vivo data are still missing, without which it is difficult to make a prediction about the future of these cells in the referred field. The paper by Kogler et al. [198] put forward some interesting data regarding the possible use of cord cells in bone tissue engineering. However, we must not forget what was reported by Rosada et al. [197], who revealed that bone marrow derived MSCs and an improved in vivo behavior regarding bone formation when directly compared to cord blood derived MSCs. The next years will dictate if these different cord cell populations can be a valid alternative to bone marrow MSCs.

\section{ADULT STEM CELLS AND ALLOGENEIC TRANSPLANTATION}

The major limit to solid organ graft survival is $\mathrm{T}$ cell recognition by the recipient antiallogen (dominated by, but not confined to MHC/HLA antigens) [204]. Commonly, two mechanisms mediate this rejection response. The first one is direct recognition by recipient CD8+ and CD4+ T cells of the donor MHC class I and class II molecules, while the second one, also known as indirect recognition involves the recognition of peptides from the allogeneic tissue [204]. Recipient antigen presenting cells (APC) such as dendritic cells (DC), process alloantigen into peptides and present these to naive T cells on self-MHC molecules [204].In the context of tissue engineering, this fact would lead to the rejection of bone and cartilage tissue engineered constructs in which allogeneic cells would have been used (i.e. osteoblasts), and so limit the application of this promising technology solely to autogenous based therapies. Besides this fact, this would lead to more extended periods of time in order to obtain the tissue engineered construct to be implanted because cells would need to be firstly isolated from a bone and cartilage biopsy, expanded and finally cultured on the 3D scaffolds. If allogenous cells could be used, the latter could be readily available from a cell bank, which of course would speed up the all process of obtaining a bone and/or cartilage tissue engineering construct. In the last years, there has been an increasing amount of literature describing the potential of adult stem cells, namely mesenchymal stem cells, to "elude" the immune system, which could then lead to an allogeneic application of these cells. For instance, different authors have shown that upon infusion or implantation, allogeneic major histocompatibility mismatched MSCs into baboons is well tolerated [205-207]

Most of the data regarding the putative allogeneic potential of MSCs comes from in vitro studies. In most of the cases, this evaluation involves the use of co-cultures or in alternative, mixed lymphocyte reactions (MLR). The outcome of the studies reported in the literature clearly indicate that mismatched MSCs do not provoke a proliferative T-cell response in allogeneic MLR, suggesting in this sense, a possible immunosuppressive role for MSCs [208-212]. For instance, Tse et al. [208] showed that MSCs were shown to differ from other cell types as no $\mathrm{T}$ cell proliferation was observed when MSCs were cultured with peripheral blood lymphocytes. Le Blanc et al. [209] also showed that MSCs failed to elicit proliferation of allogeneic lymphocytes, and that remained immunosuppressive even after IFN-gama stimulation. Furthermore, in the same report it was also shown that MSCs previously differentiated into the osteogenic, chondrogenic and adipogenic lineages, were able to inhibit proliferation on mixed lymphocyte cultures, particularly those that had been exposed to osteogenic differentiation conditions. This fact was also verified for differentiated MSCs that had been pretreated with IFN-gama. Similar results were also obtained by Majumdar and colleagues [210]. Both these reports are very interesting for tissue engineering purposes and may indicate that differentiated MSCs might also be used for allogeneic transplantation. Krampera et al. [211] also showed that MSCs had an inhibitory effect on T-cell proliferation and at the same time, they lack MHC class II. Aggarwal and Pittenger [212] reported that MSCs altered the cytokine secretion profile of dendritic cells, naive and effector T cells and natural killer cells to induce a more anti-inflammatory or tolerant phenotype. The above described reports are a clear indication of the potential of adult stem cells, and particularly MSCs, for allogeneic clinical transplantation. An example of this is the report published by Horwitz et al. [213], in which allogeneic MSCs were used as therapeutical agents for the treatment of osteogenesis imperfecta in a group of 6 children. The results showed MSCs engraftment in different sites (bone, skin and bone marrow) and that there were no major immunological reactions against them.

The reasons by which MSCs are tolerable in allogeneic environments are still fairly unknown. In a recent review by Ryan et al. [204], three candidate mechanisms, all believed to be interrelated between each other, were proposed to clarify the following phenomena: 1) MSCs could be hypoimmunogeneic; 2) MSCs may modulate T-cell phenotype and 3) MSCs can create an immunosuppressive local milieu.

The hypoimmunogenicity is probably related with the surface expression of MHC alloantigens by MSCs, although there is still some controversy regarding this fact. Most of the studies describe MSCs as being MHC class I positive and MHC class II negative [204]. The expression of MHC class I is important because its expression protects MSCs from some natural killer cells mechanisms of deletion [204]. Furthermore, as MHC class II proteins are potent antiallogens, their lack of expression by MSCs leads to a reduced immunogenicity through the control of alloantigen expression [210, 214, 215]. This MHC-II absence gives MSCs the potential to escape recognition by alloreactive CD4+ T cells [204]. Furthermore, it has also been suggested that MSCs may control DCs maturation and function. The reports by Zhang et al. [216] and Beyth et al. [217] clearly indicate that MSCs interfere with DC maturation, leaving them in a semi-mature state and thereby inducing peripheral tolerance. Therefore, MSCs can mediate allogeneic tolerance either by directing APC towards a suppressor or inhibitory phenotype resulting in an attenuated or regulatory $\mathrm{T}$ cell 
response, or directly acting on $\mathrm{CD} 4+$ cells leading them into a suppressive or counter regulatory phenotype [204]. Finally, it is also known that the production of cytokines by MSCs may produce an immunosuppressive effect in the surrounding milieu. The expression of cytokines such as IL10, HGF, TGF-B1 and prostaglandin E-2 (PGE-2), which have several functions in controlling an immunological response, is a good indicator in these conditons [204]. Nevertheless, the data reported are still quite controversial, and more studies regarding this topic need to be conducted.

\section{ADULT STEM CELL EXPANSION}

One of the current limitations for the use of ASCs in the clinics, particularly for autologous cellular transplantation, is the small number of cells that can be readily obtained, requiring therefore extensive expansion for therapeutic applications. Upon isolation, ASCs are commonly expanded in $2 \mathrm{D}$ environments, using standardized cell culture media supplemented with fetal bovine serum and antibiotics. Although this methodology has proved to be effective to grow a number of adult stem cells from different origins, it is also true that most of the success of these cultures relies on the quality of the batches of serum used, which hinders standardization that is critical to establishing a broad clinical adoption [218]. Therefore, it is essential to find defined conditions as well as growth factors that stimulate the selfrenewal and proliferation of the stem cell populations maintained in culture. As most of the work regarding the optimization of the culture conditions of adult stem cells for osteo and chondrogenic applications has been performed with MSCs, this will be used as a model for what will be discussed in the following paragraphs. One of the possible factors used to selectively expand populations of adult stem cells is the basic fibroblast growth factor (bFGF or FGF-2). In fact, FGF-2 has already shown to play a role in the selfrenewal of adult stem cells from different sources [219]. FGF-2 is a potent modulator of proliferation and activity of bone cells and MSCs [220-222]. In a report by Martin et al. [223], it was shown that FGF-2 increased the size of the CFU-Fs and at the same time, caused the maintenance of the initial fibroblastic phenotype of the cells. This suggested that referred growth factor probably favored the self-renewal and proliferation of the stem cells subpopulation within heterogeneous marrow cultures. Other results [224] revealed that FGF-2 supplemented MSCs cultures displayed an early increase in telomere size followed by a gradual decrease, whereas in control cultures, telomere length steadily decreased with increasing population doublings. Under clonogenic cultures conditions, FGF-2 supplementation prolonged the life span of MSCs to more than 70 doublings, maintaining their differentiation potential until 50 doublings. Solchaga and co-workers [225] also showed that when incubated with FGF-2, MSCs proliferated more rapidly than MSCs in control conditions. Moreover, it was also shown in this group of papers that the incubation of MSC cultures with FGF-2 increased their osteo and chondrogenic potential, when the cells were subjected to the latter conditions [223-225]. Other strategies are based on the stimulation of specific receptors present on MSCs. Tamama et al. [218] showed that by activating the Epidermal Growth Factor receptor (EGFr) using EGF, it was possible to increase the proliferation of MSCs. For an in depth study on the mechanisms of action of EGF on MSCs, it is advisable to read the work of Kratchmarova et al. [226]. Another strategy that also involves the use of growth factors but at the same time presents a different culture system, was put forward in 2003 by Baksh et al. [227]. In this particular work, it was demonstrated that it was possible to grow bone marrow derived mesenchymal progenitors under stirred suspension cultures in an adhesion-independent manner, in a culture media supplemented with interleukin 3 (IL-3) and stem cell factor (SCF). Furthermore, when directly comparing this methodology with the standard 2D static culture, it was possible to observe a higher cell proliferation rate in the suspension cultures, making therefore this particular methodology as a possible path for future upscaled industrial applications.

\section{CONCLUSION}

Adult stem cells will have an essential role in bone and cartilage tissue engineering based therapies, as we can conclude from the above discussion. All the stem cells populations presented and discussed in the present paper (bone marrow, periosteum, adipose tissue, skeletal muscle and umbilical cord) have shown to possess promising key characteristics and differentiation potential to be used for such purposes. However, all of them present advantages and disadvantages when compared between themselves. For instance, as MSCs from the bone marrow and MCLCs from the periosteum have been studied for longer periods of time and in this sense, the knowledge acquired about them is higher, it is expectable that these will lead the initial wave of adult stem cells applications in in vitro tissue engineered bone and cartilage constructs. As it was referred, this is already happening with the commercialization of the first bone tissue engineered product, in which periosteal cells are used, and definitely more products are expected for the upcoming years based on these stem/progenitor cell populations. Furthermore, the intrinsic characteristics of MSCs, namely their possible "immunoprivileged" character, and their positive behavior when transplanted in human beings has raised to a greater extent the enthusiasm of the scientific community regarding this particular cell population. However, the other ASCs populations described in this paper should not be seen as a minor or secondary choice. For instance, ADASCs and HUCPVCs, have shown an advantage regarding MSCs, presenting higher numbers of cells that are available upon isolation. Furthermore, HUCPVCs also showed a remarkable proliferation potential. Cord blood stem cells have also shown a very interesting differentiation potential, and besides that, there is no need to perform a surgery in order to obtain a biopsy, as they can be collected at birth. The main issue regarding this novel source of ASCs for bone and cartilage regeneration is their in vivo functionality, which is still missing, mainly due to the novelty and youth of their research. However, once the latter is demonstrated, they will undoubtedly be one of the main cell populations used in the field.

In order to have ASCs applied in the bone and cartilage tissue engineering field, other aspects regarding their basic biology should also be studied and further investigated. For instance, it is necessary to increase the knowledge about the 
different signaling pathways involved in the proliferation and differentiation of ASCs, and at the same time, understand how to control them. A better control of the proliferation of these cells could lead to the development of more effective expansion and differentiation methodologies. It is also necessary to know how the ASCs (differentiated or non-differentiated) present on the tissue engineered constructs will interact with the resident stem cell population on the injury site, as well as with the other cell types. Finally, and as up to now, there is unanimity regarding specific markers for these cells, therefore it is essential to further continue the studies in this area and at the same time improve the isolation methodologies, so that pure populations of ASCs can be obtained, which certainly lead to more efficient in vivo results.

\section{ACKNOWLEDGEMENTS}

The authors would like to acknowledge Portuguese Foundation for Science and Technology through funds from POCTI and/or FEDER programs (Post-Doctoral fellowship to A.J. Salgado (SFRH/BPD/17935/2004) and PhD scholarship to J.T. Oliveira (SFRH/BD/17135/2004)), and EU STREP project HIPPOCRATES (NMP3-CT-2003505758)

\section{REFERENCES}

[1] Blau HM, Brazelton TR, Weimann JM. The evolving concept of a stem cell: entity or function?. Cell 2001; 105: 829-841

[2] Lin H. The tao of stem cell in germline. Annu Rev Genet 1997, 31: $455-491$

[3] Jackson KA, Majka SM, Wulf GG, Goodel MA. Stem Cells: A minireview. J Cell Biochem 2001; S38: 1-6.

[4] Allison MR, Poulsom R, Forbes S, Wright NA. An introduction to stem cells. J Pathol 2002; 197: 419-423.

[5] Preston SL, Alison MR, Forbes SJ, Direkze NC, Poulsom R, Wright NA. The new stem cell biology: something for everyone. Molec Pathol 2003; 56: 86-96.

[6] Martin GR. Isolation of a pluripotent cell line from early mouse embryos cultured in medium conditioned by teratocarcinoma stem cells. Proc Natl Acad Sci 1981; 78: 7634-7638.

[7] Evans MJ, Kaufman MH. Establishment in culture of pluripotential cells from mouse embryos. Nature 1981; 292: 154156.

[8] Thomson JA, Itskovitz J, Shapiro SS, Waknitz MA, Swiergiel JJ, Marshal VS, Jones JM. Embryonic stem cell lines derived from human blastocysts. Science 1998; 282: 1145-1147.

[9] Reubinoff BE, Pera MF, Fong CY, Trounson A, Bongso A, Embryonic stem cell lines from human blastocysts: somatic differentiation in vitro. Nature Biotechnol 2000; 18: 399-404.

[10] Wobus AM, Guan KM. Embryonic stem cell-derived cardiac differentiation: Modulation of differentiation and "loss-offunction" analysis in vitro. Trends Cardiov Med 1998; 8: 64

[11] Wiles MV, Keller G. Multiple hematopoetic lineages develop from embryonic stem cells (ES) in culture. Development 1991 111(2): 259-267.

[12] Wang R, Clark R, Bautch VL. Embryonic stem cell-derived cystic embryoid bodies form vascular channels: an in vitro model of blood vessel development. Development 1992; 114(2): 303-316.

[13] Yamashita J, Itoh H, Hirashima M, Ogawa M, Nishikawa S, Yurugi T, Naito M, Nakao K, Nishikawa S. Flk-1 positive cells derived from embryonic stem cells serve as vascular progenitors. Nature 2000; 408: 92-96

[14] Guan KM, Chang H, Rolletschek V, Wobus AM, Embryonic stem cells derived neurogenesis. Retinoic acid induction and lineage selection of neuronal cells. Cell Tissue Res 2001; 305(2): 171-176.
[15] Schuldiner M, Eiges R, Eden A, Yanuka O, Itskovitz-Eldor J, Goldstein RS, Benvenistry N. Induced neuronal differentiation of human embryonic stem cells. Brain Res 2001; 913(2): 201-205.

[16] Bielby RC, Bocaccini AR, Polak JM, Buttery LD. In vitro differentiation and in vivo mineralization of osteogenic cells derived from human embryonic stem cells. Tissue Eng 2004; 10 1518-1525

[17] Tai G, Polak JM, Bishop AE, Christodoulou I, Buttery LD Differentiation of osteoblasts from murine embryonic stem cells by overexpression of the transcriptional factor osterix. Tissue Eng 2004; 10: 1456-1466.

[18] Buttery LD, Bourne S, Xynos JD, Wood H, Hughes F, Hughes SP Episkopou V, Polak JM. Differentiation of osteoblasts and in vitro bone formation from murine embryonic stem cells. Tissue Eng 2001; 7: 89-99.

[19] Tanaka H, Murphy CL, Murphy C, et al. Chondrogenic differentiation of murine embryonic stem cells: effects of culture conditions and dexamethasone. J Cell Biochem 2004; 93: 454-462.

[20] Hwang NS, Kim MS, Sampattavanich S, et al. The effects of three dimensional culture and growth factors on the chondrogenic differentiation of murine embryonic stem cells. Stem Cells 2005, in press.

[21] Dani C. Embryonic stem cell derived adipogenesis. Cells Tissues Organs 1999; 165: 173-180

[22] Dani C, Smith AG, Dessolin S, et al. Differentiation of embryonic stem cells into adipocytes in vitro. J Cell Sci 1997; 110: 1279-1285.

[23] Hamazaki T, Iiboshi $\mathrm{Y}$, Oka M, et al. Hepatic maturation in differentiating embryonic stem cells into hepatocytes. FEBS Lett 2001; 497: 15-19.

[24] Choi DH, Oh HJ, Chang UJ, et al. In vivo differentiation of mouse embryonic stem cells into hepatocytes. Cell Transplantation 2002: 11: 359-368.

[25] Shiroi A, Yoshikawa M, Yokota $\mathrm{H}$, et al. Identification of insulin producing cells derived from embryonic stem cells by zincchelating dithizone. Stem Cells; 20: 284-292.

[26] Klimankaya I, Hipp J, Rezai K, et al. Derivation and comparative assessment of retinal pigment epithelium from human embryonic stem cells using transcriptomics. Cloning Stem Cells 2004; 6: 215245.

[27] Haruta M, Sasai $\mathrm{Y}$, Kawasaki $\mathrm{H}$, et al. In vitro and in vivo characterization of pigment epithelial cells differentiated from primate embryonic stem cells. Invest Ophthalmol Vis Sci 2004; 45 1020-1025

[28] Wobus AM. Potential of embryonic stem cells. Mol Aspects Med 2001: 22: 149-164

[29] Pittenger MF, Mackay AM, Beck SC, et al. Multilineage potential of adult mesenchymal stem cells. Science $1999 ; 284: 143-147$.

[30] Hanada K, Solchaga LA, Caplan AI, et al. BMP-2 induction and TGF- $\beta 1$ modulation of rat peristeal cell chondrogenesis. J Cell Biochem 2001; 26: 284-294.

[31] Perka C, Schultz O, Spitzer RS, et al. Segmental bone repair by tissue-engineered periosteal cell transplants with bioresorbable fleece and fibrin scaffolds in rabbits. Biomaterials 2000; $11: 1145$ 1153

[32] Asakura A, Komaki M, Rudnicki MA. Muscle satellite cells are multipotential stem cells that exhibit myogenic, osteogenic and adipogenic differentiation. Differentiation 2001; 68: 245-253

[33] Lee JY, Qu-Peterson Z, Baohong C, et al. Clonal isolation of muscle-derived cells capable of enhancing muscle regeneration and bone healing. J Cell Biol 2000; 150: 1085-1099.

[34] Zuk PA, Zhu M, Mizuno H, et al. Multilineage cells from human adipose tissue: implications for cell-based therapies. Tissue Eng 2001; 7: 211-228.

[35] McKay R. Stem cells in the central nervous system. Science 1997; 276: 66-71

[36] Gage FH. Mammalian neural stem cells. Science 2000; 287: 14331438

[37] Toma JG, Akhavan M, Fernades KJ, et al. Isolation of multipotent adult stem cells from the dermis of mammalian skin. Nat Cell Biol 2001; 3: 778-784.

[38] Erices A, Concet $\mathrm{P}$, Minguell J. Mesenchymal progenitor cells in human umbilical cord blood. Br J Haemat 2000; 109: 235-242

[39] Romanov YA, Svintsitskaya VA, Smirnov VN. Searching for alternative sources of postnatal human mesenchymal stem cells: candidate msc-like cells from umbilical cord. Stem Cells 2003; 21 : 105-110. 
[40] Sarugaser R, Lickorish D, Baksh D, Hosseini MM, Davies JE. Human umbilical cord perivascular (HUCPV) cells: a source of mesenchymal progenitors. Stem Cells 2004; 23: 220-229.

[41] Sommerfeldt DW, Rubin CT. Biology of bone and how it orchestrates the form and function of the skeleton. Eur Spine J; 10(S2): S86-S95.

[42] Rodan GA. Introduction to bone biology. Bone 1992; 13(S1): S3S6-

[43] Le Baron RG, Athanasiou K. Ex vivo synthesis of articular cartilage. Biomaterials $2000 ; 21: 2575-2587$

[44] Sikavitsas VI, Temenoff JS, Mikos AG. Biomaterials and bone mechanotransduction. Biomaterials 2001; 2581-2593

[45] Hill PA. Bone Remodelling. Br J Orthod 1998; 25: 101-107.

[46] Baron R, "Primer on the Metabolic Bone Diseases and Disorders of Mineral Metabolism", $2^{\text {nd }}$ edition, Raven Press, New York, pp. 3.

[47] Knothe Tate ML, Adamson JR, Tami AE, Bauer TW. The osteocyte. Int J Biochem Cell Biol 2004; 36: 1-8

[48] Vaananen K, "Principles of Bone Biology ", $1^{\text {st }}$ Edition, Academic Press, San Diego 1996, pp. 103.

[49] Rossert J, De Crombrugghe B, "Principles of Bone Biology ", $1^{\text {st }}$ Edition, Academic Press, San Diego 1996, pp. 127.

[50] Triffit JT, "Principles of Bone Biology ", $1^{\text {st }}$ Edition, Academic Press, San Diego 1996, pp. 39.

[51] Termine JD, "Primer on the Metabolic Bone Diseases and Disorders of Mineral Metabolism", $2^{\text {nd }}$ Edition, Raven Press, New York 1993, pp. 21

[52] Robey PG, "Principles of Bone Biology ", $1^{\text {st }}$ Edition, Academic Press, San Diego 1996, pp. 155

[53] Buttler WT, Ridall AL, McKee MD, "Principles of Bone Biology ", It $^{\text {st }}$ Edition, Academic Press, San Diego 1996, pp. 167.

[54] Sodek J, Ganss B, McKee MD. Osteopontin. Crit Rev Oral Bio Med 2000; 11: 279-303.

[55] Salgado AJ, Gomes ME, Coutinho OP, Reis RL. In: Reis RL and San Roman J, Biodegradable Systems in Medical Functions: Design, Processing, Testing and Application, CRC Press 2004; 457-478.

[56] Aubin JE, Liau F, "Principles of Bone Biology ", $1^{\text {st }}$ Edition, Academic Press, San Diego 1996, pp. 51

[57] Ducy P, Schinke T, Karsenty G. The osteoblast: a sophisticated fibroblast under central surveillance. Science 2000; 289: 1501.1504

[58] Cancedda R, Descalzi Cancedda F, Castagnola P. Chondrocyte differentiation. Int Rev Cytol 1995; 159: 265-358.

[59] Seibel M. In: Seibel M, Robins S, Bilezikian J, Dynamics of Bone and Cartilage Metabolism, Academic Press 1999, 301.

[60] Christgau S, Cloos PAC. Cartilage degradation products as markers for evaluation of patients with rheumatic disease. Clinical and Applied Immunology Reviews 2004; 4(4): 277.

[61] Newman AP. Articular cartilage repair. Am J Sports Med 1998; 26(2): 309-24

[62] Buckwalter JA, Martin J, Mankin HJ. Synovial joint degeneration and the syndrome of osteoarthritis. Instr Course Lect 2000; 49: 481-9.

[63] Reginato AM, Olsen BR. The role of structural genes in the pathogenesis of osteoarthritic disorders. Arthritis Res 2002; 4(6): $337-45$.

[64] Carver SE, Heath CA. Semi-continuous perfusion system for delivering intermittent physiological pressure to regenerating cartilage. Tissue Eng 1999; 5(1): 1-11.

[65] Archer CW, Francis-West P. The chondrocyte. Int J Biochem Cell Biol 2003; 35(4): 401-4

[66] Hunziker EB, Quinn TM, Hauselmann HJ. Quantitative structural organization of normal adult human articular cartilage. Osteoarthritis Cartilage 2002; 10(7): 564-72.

[67] Park SS, Jin HR, Chi DH, Taylor RS. Characteristics of tissueengineered cartilage from human auricular chondrocytes. Biomaterials 2004; $25(12): 2363-9$.

[68] Cancedda R, Dozin B, Giannoni P, Quarto R. Tissue engineering and cell therapy of cartilage and bone. Matrix Biol 2003; 22(1): $81-91$

[69] Woolf AD, Pfleger B. Burden of major musculoskeletal conditions. Bulletin of the World Health Organization 2003; 81: 646-656.
[70] Badley EM, Rasooly I, Webster GK. Relative importance of musculoskeletal disorders as a cause of chronic health problems, disability, and health care utilization: finding from the 1990 ontario health survey. J Rheumat 1994; 21: 505-514

[71] Reynolds DI, Chambers LW, Badley EM, et al. Physical disability among Canadians reporting musculoskeletal diseases, J Rheumat 1992; 19: 1020-1030

[72] Temenoff JS, Mikos AG. Review: tissue engineering for regeneration of articular cartilage. Biomaterials 2000; 21(5): 43140.

[73] http: //www.aoa.gov/prof/Statistics/statistics_pf.asp. [cited 2005 7th October 2005]

[74] http: //www.bioportfolio.com/reports/DMD_Cell_Therapy.htm. 1st February 2003 [cited 7th October 2005]

[75] Bruder SP, Fox BS. Tissue engineering of bone: Cell based strategies. Clin Orthop 1999; 367S: S68-S83.

[76] Inoue K, Ohgushi K, Yoshikawa T, et al. The effect of aging on bone formation in porous hydroxyapatite : biochemical and histological analysis. J Bone Miner Res 1997; 12(6): 989-994.

[77] D'Ippolito G, Schiller PC, Ricordi C, et al. Age related osteogenic potential of mesenchymal stromal stem cells from human vertebral bone marrow. J Bone Min Res 1999; 14(7): 115-122.

[78] Mendes SC, Tibbe JM, Veenhof M, et al. Bone tissue-engineered implants using human bone marrow stromal cells : effect of culture conditions and donor age. Tissue Eng. 2002; 8(6): 911 920

[79] Caplan AI, Bruder SP. Mesenchymal stem cells: building blocks for molecular medicine in the 21 st century. Trends in Molecular Medicine 2001; 7(6): 259

[80] Tsuchiya $\mathrm{H}$, Kitoh $\mathrm{H}$, Sugiura $\mathrm{F}$, Ishiguro N. Chondrogenesis enhanced by overexpression of sox 9 gene in mouse bone marrow-derived mesenchymal stem cells. Biochemical and Biophysical Research Communications 2003; 301(2): 338 .

[81] Palmer GD, Steinert A, Pascher A, et al. Gene-Induced Chondrogenesis of Primary Mesenchymal Stem Cells in vitro. Molecular Therapy 2005; 12(2): 219 .

[82] Langer R, Vacanti JP. Tissue Engineering. Science 1993; 260 920-926.

[83] Kneser U, Schaefer DJ, Munder B, et al. Tissue engineering of bone. Min Invas Ther \& Allied Technol 2.002; 11(3): 107-116.

[84] Laurencin CT, Ambrosio AMA, Borden MD, Cooper JA. Tissue engineering: orthopedic applications. Annu Rev Biomed Eng 1999; 1: 19-46.

[85] Salgado AJ, Coutinho OP, Reis RL. Bone tissue engineeering: state of art and future trends. Macromol Biosc 2004; 4: 743-765.

[86] Laurencin CT, Attawia MA, Elgendy HE, Herbert KM. Tissue engineering bone-regeneration using degradable polymers: the formation of mineralized matrices. Bone 1996; S1: 93S-99S

[87] Brittberg M, Lindahl A, Nilsson A, Ohlsson C, Isaksson O, Peterson L. Treatment of deep cartilage defects in the knee with autologous chondrocyte transplantation. N Engl J Med 1994; 331: 889-895

[88] Suh JK, Matthew HW. Application of chitosan-based polysaccharide biomaterials in cartilage tissue engineering: a review. Biomaterials 2000; 21: 2589-98.

[89] Kadiyala S, Young RG, Thiede MA, Bruder SP. Culture expanded canine mesenchymal stem cells possess osteochondrogenic potential in vivo and in vitro. Cell Transplantation 1997; 6: 125134.

[90] Nilsson SK, Dooner MS, Weier HU, et al.Cells capable of bone production engraft from whole bone marrow transplants in nonablated mice. J Exp Med 1999; 189: 729-734.

[91] Jaiswal N, Haynesworth SE, Caplan AI, Bruder, S.P. Osteogenic differentiation of purified, culture-expanded human mesenchymal stem cells in vitro. J Cellular Biochem 1997; 64, 295-312.

[92] Mackay AM, Beck SC, Murphy JM, et al., Chondrogenic differentiation of cultured human mesenchymal stem cells from marrow. Tissue Eng 1998; 4: 415-428.

[93] Johnstone B, Hering TM, Caplan AI, et al. In vitro chondrogenesis of bone marrow-derived mesenchymal progenitor cells. Exp Cell Res 1998; 238: 265-272.

[94] Endres M, Hutmacher DW, Salgado AJ, et al. Osteogenic induction of human bone marrow-derived mesenchymal progenitor cells in novel synthetic polymer-hydrogel matrices. Tissue Eng 2003; 9: 689-702.

[95] Awad HA, Butler DL, Boivin GP, et al. Autologous mesenchymal stem cell-mediated repair of tendon. Tissue Eng 1999; 5: 267-277. 
[96] Young RG, Butler DL, Weber W, et al. Use of mesenchymal stem cells in a collagen matrix for Achilles tendon repair. J Orthopaed Res 1998; 16: 406-413.

[97] Bhabavati S, Xu W. Isolation and enrichment of skeletal muscle progenitor cells from mouse bone marrow. Biochem Biophys Res Commun 2004; 21: 119-124

[98] Friedenstein AJ, Deriglasova UF, Kulagina NN, et al Precursors for fibroblasts in different populations of hematopoietic cells as detected by the in vitro colony assay method. Exp Hematol 1974 2: 83-92.

[99] Haynesworth SE, Goshima J, Goldberg VM, Caplan AI Characterization of cells with osteogenic potential from human marrow. Bone 1992; 13: 81-88.

[100] Tuan S, Genevieve B, Tuli R. Adult mesenchymal stem cells and cell-based tissue engineering. Arthrtis Res Ther 2003; 5: 32-45.

[101] Deans RJ, Moseley AB. Mesenchymal stem cells: Biology and potential clinical uses. Exp Hematol 2000; 28(8): 875.

[102] Haynesworth SE, Baber MA, Caplan, A.I. Cell-Surface Antigen on Human Marrow-Derived Mesenchymal Cells Are Detected by Monoclonal-Antibodies. Bone 1992; 13: 69-80

[103] Bruder SP, Horowitz MC, Mosca JD, Haynesworth SE. Monoclonal antibodies reactive with human osteogenic cell surface antigens. Bone 1997; 21: 225-235

[104] Bruder SP, Ricalton NS, Boynton RE, et al. Mesenchymal stem cell surface antigen SB-10 corresponds to activated leukocyte cell adhesion molecule and is involved in osteogenic differentiation. J Bone Min Res 1998; 13: 655-663.

[105] . Barry F, Boynton R, Murphy M, Haynesworth S, Zaia J. The SH-3 and $\mathrm{SH}-4$ antibodies recognize distinct epitopes on $\mathrm{CD} 73$ from human mesenchymal stem cells. Biochem Bioph Res Com 2002; 290: 1609-1609

[106] Ringe J, Kaps C, Burmester GR, Sittinger M. Stem cells for regenerative medicine advances in the engineering of tissues and organs. Naturwissenschaften $\mathbf{8 9}, 338-351$.

[107] Roufosse CA, Direkze NC, Otto WR, Wright NA, Circulating Mesenchymal Stem Cells. In J Biochem Cell Biol 2004; 36: 585597.

[108] Bellows CG, Heersche JN, Aubin JE. Determination of the capacity for proliferation and differentation of osteoprogenitorcell in the presence of dexamethasone. Dev Biol 1990; 140: 132-138.

[109] Chung CH, Golub EE, Forbes E, Tokuoka T, Shapiro IM Mechanisms of action of beta-glycerophosphate on bone cell mineralization. Cell Tissue Int 1992; 51: 212-219.

[110] Tenembaum HC, Limeback H, McCulloch CA, et al. Osteogenic phase-specific co-regulation of collagen synthesis and mineralization by beta-glycerophosphate in chick periosteal cultures. Bone 1992; 13: 129-138.

[111] Ducy P, Zhan R, Geoffroy V, Ridall AL, Karsenty G. Osf2/Cbaf1 a transcriptional activator of osteoblast differentiation. Cell 1997 89: $747-754$

[112] Hosseini MM, Sodek J, Franke RP, Davies JE. In: Davies JE, $\mathrm{m}^{2}$ 1999, 295-304

[113] Liu P, Oyajobi BO, Russel RG, Scutt A. Regulation of osteogenic differentiation of human bone marrow stromal cells: interaction between transforming growth fact beta and $1,25(\mathrm{OH})(2)$ vitamin $\mathrm{D}(3)$ in vitro. Calcif Tissue Int 1999; 65: 173-180.

[114] Hanada K, Dennis JE, Caplan AI. Stimulatory effects of basic fibroblast growth factor and bone morphogenetic protein 2 on osteogenic differentiation of rat bone marrow derived mesenchymal stem cells. J Bone Min Res 1997; 12: 1606-1614.

[115] Gomes ME, Sikavitsas VI, Beharavesh E, Reis RL, Mikos AG. Effect of flow perfusion on the osteogenic differentiation of bone marrow stromal cells cultured on starch based three dimensional scaffolds. J Biomed Mat Res 2003; 67: 87-95

[116] Sikavitsas VI, Bancroft GN, Holtorf HL, Jansen JA, Mikos AG Mineralized matrix deposition by marrow stromal osteoblasts in 3D perfusion culture increases with increasing fluid shear stresses. Proc Nat Acad Sci 2003; 100: 14683-14688.

[117] Holtorf HL, Jansen JA, Mikos AG. Flow perfusion culture induces the osteoblastic differentiation of marrow stroma cell-scffold constructs in the absence of dexamethasone. J Biomed Mat Res 2005; $72: 326-334$

[118] Sikavitsas VI, Bancroft GN, Lemoine JJ, et al. Flow perfusion enhances the calcified matrix deposition of marrow stromal cells in biodegradale nonwoven fiber mesh scaffolds. Ann Biomed Eng 2005; 33: 63-70.

[119] Byers BA, Guldberg RE, Garcia AJ. Synergy between genetic and tissue engineering: runx2 overexpression and in vitro construct development enhance in vivo mineralization. Tissue Eng 2004; 10: 1757-1766

[120] Salasznyk RM, Klee RF, Hughlock MK, Plopper GF. ERK signalling pathways regulate the osteogenic differentiation of human mesenchymal stem cells on collagen I and vitronectin. Cell Commun Adhes 2004; 11: 137-153.

[121] Yang XB, Bhatnagar RS, Li S, Oreffo R. Biomimetic collagen scaffolds for human bone cell growth and differentiation. Tissue Eng 2004; 10: 1148-1159.

[122] Salasznyk RM, Williams WA, Boskey A, Batorsky A, Plopper GE. Adhesion to vitronectin and collagen I promotes osteogenic differentiation of human mesenchymal stem cells. J Biomed Biotechnol 2004; 1: 24-34.

[123] Murphy Wl, Hsiong S, Richardson TP, Simmons CA, Mooney DJ. Effects of bone-like mineral film on phenotype od adul mesenchymal stem cells in vitro. Biomaterials 2005; $26: 303-310$.

[124] Salgado AJ, Figueiredo JE, Coutinho OP, Reis RL. Biological response to pre-mineralized starch based scaffolds for bone tissue engineering. J Mater Sci Mater Med 2005; 16: 267-275.

[125] de Boer J, Wang HJ, van Blitterswijk C. Effects of Wnt signaling on proliferation and differentation of human mesenchymal stem cells. Tissue Eng 2004; 10: 393-401.

[126] Etheridge SL, Spencer GJ, Heath DJ, Genever PG. Expession profile and functional analysis of Wnt signalling mechanisms in mesenchymal stem cells. Stem Cells 2004; 22: 849-860.

[127] de Boer J, Ramakrishnaiah S, Gaspar C, et al. Wnt signalling inhibits osteogenic differentaition of human mesenchymal stem cells. Bone 2004: $34: 818-826$

[128] Boland GM, Perkins G, Hall DJ, et al. Wnt 3a promotes proliferation and suppresses osteogenic differentiation of adul human mesenchymal stem cells. J Cell Biochem 2004; 93(6) 1210-30.

[129] Fischer L, Boland G, Tuan RS. Wnt-3A enhances bone morphogenetic protein-2-mediated chondrogenesis of murine C3H10T1/2 mesenchymal cells. J Biol Chem. 2002; 277(34) 30870-30878.

[130] Gregory CA, Gunn WG, Reyes E, et al. How Wnt signalling affects bone repair by mesenchymal stem cells from the bone marrow. Ann NY Acad Sci 2005; 1049: 97-106.

[131] Petit H, Viautveau V, Bensaid W, et al. Tissue engineered bone regeneration. Nat Biotechnol 2000; 18 :959-963.

[132] Holy CE, Fialkov JA, Davies JE, Shoichet MS. Use of a biomimetic strategy to engineer bone. J Biomed Mat Res A 2003, 65: 447-453.

[133] Quarto R, Mastrogiacomo, Cancedda R, et al. Repair of large bone defects with the use of autologous bone marrow stroma cells. N Eng J Med 2001; 344: 385-386.

[134] Martin I, Padera RF, Vunjak-Novakovic G, Freed LE. In vitro differentiation of chick embryo bone marrow stromal cells into cartilaginous and bone-like tissues. J Orthop Res 1998; 16(2): 1819.

[135] Wakitani S, Goto T, Pineda SJ, et al. Mesenchymal cell-based repair of large, full-thickness defects of articular cartilage. J Bone Joint Surg Am 1994; 76(4): 579-92.

[136] Wang Y, Kim U-J, Blasioli DJ, Kim H-J, Kaplan DL. In vitro cartilage tissue engineering with $3 \mathrm{D}$ porous aqueous-derived silk scaffolds and mesenchymal stem cells. Biomaterials 2005; In Press.

[137] Li W-J, Tuli R, Okafor C, et al. A three-dimensional nanofibrous scaffold for cartilage tissue engineering using human mesenchymal stem cells. Biomaterials 2005; 26(6): 599.

[138] Chen G, Liu D, Tadokoro M, et al. Chondrogenic differentiation of human mesenchymal stem cells cultured in a cobweb-like biodegradable scaffold. Biochem Biophys Res Commun 2004 322(1): 50

[139] Uematsu K, Hattori K, Ishimoto $\mathrm{Y}$, et al. Cartilage regeneration using mesenchymal stem cells and a three-dimensional poly lactic-glycolic acid (PLGA) scaffold. Biomaterials 2005; 26(20): 4273

[140] M. Radice PBRCRSCBGA. Hyaluronan-based biopolymers as delivery vehicles for bone-marrow-derived mesenchyma progenitors. J Biomed Mat Res 2000; 50(2): 101-109. 
[141] Wayne JS, McDowell CL, Shields KJ, Tuan RS. In vivo Response of Polylactic Acid Alginate Scaffolds and Bone Marrow-Derived Cells for Cartilage Tissue Engineering. Tissue Eng 2005; 11(5-6): 953-963.

[142] Chen J, Wang C, Lu S, et al. In vivo Chondrogenesis of adult bone marrow derived autologous mesenchymal stem cells. Cell Tissue Res 2005; 319: 429-438.

[143] Im G, Jung N-H, Tae S. Chondrogenic differentiation of mesenchymal stem cells isolated from patients in the late adulthood: The optimal conditions of growth factors. Tissue Eng 2006; 12(3): 527-536.

[144] Sekiya I, Larson BL, Vuoristo JT, Reger RL, Prockop DJ. Comparison of effect of BMP-2, -4 , and -6 on in vitro cartilage formation of human adult stem cells from bone marrow stroma. Cell Tissue Res 2005; 320(2): 269-76.

[145] Hegewald AA, Ringe J, Bartel J, et al. Hyaluronic acid and autologous synovial fluid induce chondrogenic differentiation of equine mesenchymal stem cells: a preliminary study. Tissue Cell $2004 ; 36(6): 431-8$

[146] Indrawattana N, Chen G, Tadokoro M, et al. Growth factor combination for chondrogenic induction from human mesenchymal stem cell. Biochem Biophys Res Com 2004; 320(3): 914.

[147] Tsuchiya K, Chen G, Ushida T, Matsuno T, Tateishi T. The effect of coculture of chondrocytes with mesenchymal stem cells on their cartilaginous phenotype in vitro. Mat Sci Eng C 2004; 24(3): 391.

[148] Taylor IF. The periosteum and bone growth. Bone 1992; 6: 21 .

[149] Hutmacher DW, Sittinger M. Periosteal cells in bone tissue engineering. Tissue Engineering 2003; 9(S1): S45-S64.

[150] Muramatsu K, Bishop AT. Cell repopulation in vascularized bone grafts. J Orthop Res 2002; 20: 772-778.

[151] Fang J, Hall BK. In vitro differentiation potential of the periosteal cells from a membrane bone, the quadratojugal of the embryonic chick. Dev Biol 1996; 180: 701-712.

[152] Nakahara H, Bruder SP, Haynesworth SE, et al. Bone and cartilage formation in diffusion chambers by subcultured cells derived from the periosteum. Bone 1990; 11(3): 181 .

[153] O'Driscoll SW, Saris DB, Ito Y, Fitzimmons JS. The chondrogenic potential of periosteum decreases with age. J Orthop Res 2001; 19(1): 95-103.

[154] Nakata K, Nakahara H, Kimura T, et al. Collagen gene expression during chondrogenesis from chick periosteum-derived cells. FEBS Lett 1992; 299(3): 278

[155] Nakahara H, Bruder SP, Haynesworth SE, et al. Bone and cartilage formation in diffusion chambers by subcultured cells derived from the periosteum. Bone 1990; 11(3): 181-8.

[156] Vacanti CA, Bonassar LJ, Vacanti MP Shufflebarger J. Replacement of an avulsed phalanx with tissue-engineered bone. N Eng J Med 2001; 30: 1511-1514.

[157] Schantz JT, Hutmacher DW, Chim, et al. Induction of ectopic bone formation using humans periosteal cells in combination with a novel scaffold technology. Cell Transplant 2002; 11: 125-138.

[158] Schmelzeisen R, Schimming R, Sittinger M. Making bone: Implant insertion into tissue-engineered bone for maxillary sinus floor augmentation-a preliminary report. J. Craniomaxillfac. Surg. 2003; 31:34-39.

[159] O'Driscoll SW. Articular cartilage regeneration using periosteum. Clin Orthop Relat Res 1999(367 Suppl): S186-203.

[160] O'Driscoll SW, Fitzsimmons JS. The role of periosteum in cartilage repair. Clin Orthop Relat Res 2001(391 Suppl): S190207.

[161] Marini RP, Stevens MM, Langer R, Shastri VP. Hydraulic elevation of the periosteum: a novel technique for periosteal harvest. J Invest Surg 2004; 17(4): 229-33.

[162] Stevens MM, Qanadilo HF, Langer R, Prasad Shastri V. A rapidcuring alginate gel system: utility in periosteum-derived cartitage tissue engineering. Biomaterials 2004; 25(5): 887

[163] Stevens MM, Marini RP, Martin I, Langer R, Prasad Shastri V. FGF-2 enhances TGF-betal-induced periosteal chondrogenesis. J Orthopaed Res 2004; 22(5): 1114

[164] Huang JI, Hedrick MH, Lorenz HP, Zhu M, Benhaim P. Chondrogenesis of human adipo-derived mesodermal stem cells. J Ame Coll Surg 2000; 191 (S1): S47.

[165] Spangrude G J. When is a stem cell really a stem cell? Bone Marrow Transplant 2003; 32(S1): S7-11.
[166] Boquest AC, Shahdadfar A, Fronsdal K, et al. Isolation and Transcription Profiling of Purified Uncultured Human Stromal Stem Cells: Alteration of Gene Expression after In vitro Cell Culture. Mol Bio Cell 2005; 16: 1131-1141

[167] Zuk PA, Zhu M, Ashjian P, et al. Human adipose tissue is a source of multipotent stem cells. Mol Biolo Cell 2002; 13: 4279-4295.

[168] Gronthos S, Franklin DM, Leddy HA, et al. Surface protein characterization of human adipose tissue-derived stromal cells. J Cell Physiol 2001; 189: 54-63.

[169] Rodbell M. Metabolism of isolated fat cells. I. effects of hormones on glucose metabolism and lipolysis. J Biol Chem 1964; 239: 375 380 .

[170] Gimble J, Guilak F. Adipose-derived adult stem cells: isolation, characterization, and differentiation potential. Cytotherapy 2003 5: 362-369.

[171] Rodriguez AM, Elabd C, Amri E-Z, Ailhaud G, Dani C. The human adipose tissue is a source of multipotent stem cells. Biochimie 2005; 87: 125 .

[172] Baksh D, Song L, Tuan RS. Adult mesenchymal stem cells characterization, differentiation, and application in cell and gene therapy. J Cell Mol Med 2004; 8: 301-316, 2004.

[173] Dragoo JL, Choi JY, Lieberman JR, et al. Bone induction by BMP2 transduced stem cells derived from human fat. J Orthop Res 2003; 21: 622-629.

[174] Hicok KC, Du Laney TV, Zhou YS, et al. Human adipose-derived adult stem cells produce osteoid in vivo. Tissue Eng 2004; 10:371380

[175] Awad HA, Wickham MQ, Leddy HA, Gimble JM, Guilak F Chondrogenic differentiation of adipose-derived adult stem cells in agarose, alginate, and gelatin scaffolds. Biomaterials 2004; 25 3211-3222, 2004

[176] Betre H, Ong SR, Guilak F, et al. Chondrocytic differentiation of human adipose-derived adult stem cells in elastin-like polypeptide. Biomaterials 2006; 27: 91-99, 2006.

[177] Gimble JM, Guilak F. Differentiation Potential of Adipose Derived Adult Stem (ADAS) Cells, in Current Topics in Developmental Biology Academic Press, 2003, pp. 137.

[178] Cowan CM, Shi YY, Aalami OO, et al. Adipose-derived adult stromal cells heal critical-size mouse calvarial defects. Nat Biotechnol 2004; 22: 560-567.

[179] Wada RW, Inagawa-Ogasgiwa M, Shimizu S, Yasumoto S, Hashimoto N. Generation of different fates from multipotent muscle stem cells. Development 2002; 129: 2987-2995.

[180] O'Brien K, Muskiewicz K, Gussoni E. Recent advances in and therapeutic potential of muscle derived stem cells. J Cell Biochem 2002; S38: 80-87.

[181] Mauro A. Sattelite cells of skeletal muscle fibres. J Biophys Biochem Cyt 1961; 9: 493-495.

[182] Katz B. The terminations of the afferent nerve fibre in the muscle spindle of the frog. Philos Trans Royal Soc Lond [Bio] 1961;243: 221-240.

[183] Zammit PS, Beauchamp JR. The sekeletal muscle satellite cell: stem cells or son of the stem cell?. Differentation 2001; 68: 193 204.

[184] Peng H., Huard J. Muscle-derived stem cells for musculoskeletal tissue regeneration and repair. Transplant Immunol 2004; 12: 311 319.

[185] Qu-Petersen Z, Deasy B, Jankowsky R. Identification of a novel cell population of muscle stem cells in mice: potential for muscle regeneration. J Cell Biol 2002; 157: 851-864

[186] McKinney-Freeman SL, Jackson KA, Camargo FD, et al. Muscle derived hematopoietic stem cells are hematopoietic in origin. Proc. Nat Acad Sci 2002; 99: 1341-1346.

[187] Adachi N, Sato K, Usas A, et al. Muscle derived, cell based ex vivo gene therapy for treatment of full thickness articula cartilage defects. J Rheumat 2002; 29: 1920-1930.

[188] Cao B, Huard J. Muscle Derived Stem Cells. Cell Cycle 2004; 3 104-107.

[189] Torrente Y, Tremblay JP, Pisati F, et al. Intraarterial injection of muscle-derived CD34(+)Sca-1(+) stem cells restores dystrophin in mdx mice. J Cell Biol 2001; 152:335-348.

[190] Qu Z, Balkir L, van Deutekom JC, Robbins PD, Pruchnic R, Huard J. Development of approaches to improve cell survival in myoblast transfer therapy. J Cell Biol 1998; 142: 1257-1267.

[191] Wright V, Peng H, Usas A, et al. BMP-4 expressing muscle derived stem cells differentiate into osteogenic lineage and 
improve bone healing in immunocompetent mice. Mol Ther 2002 6: $169-178$.

[192] Peng H, Chen ST, Wergedal JE, et al. Development of a MGF based retroviral vector system for secretion of high levels of functional active human BMP-4. Mol The 2001; 4: 95-104

[193] Lee JY, Peng H, Usas A, et al. Enhancement of bone healing based ex vivo therapy using human muscle-derived cells expressin bone morphogenetic protein 2. Human Gene Ther 2002 13: 1201-1211.

[194] Gang EJ, Hong SH, Jeong JA, et al. In vitro mesengenic potentia of human umbical cord blood-derived mesenchymal stem cells. Biochem Biophy Res Commun 2004; 321: 102-108.

[195] Lee OK, Kuo TK, Chen W-M, et al. Isolation of multipotent mesenchymal stem cells from umbilical cord blood. Blood 2004; 103: $1669-1675$

[196] Tondreau T, Meuleman N, Delforge A, et al. Mesenchymal stem cells derived from CD133-positive cells in mobilized perihera blood and cord blood: proliferation, oct 4 expression and plasticity Stem Cells 2005; 23: 1105-1112.

[197] Rosada C, Justesen J, melsvik D, Ebbesen P, Kassem M. The human umbilical cord blood: a potential source for osteoblast progenitor cells. Calcif Tissue Int 2003; 72: 135-142

[198] Kogler G, Sensken S, Airey JA, et al. A new human somatic stem cells from placental cord blood with intrinsic pluripotent differentiation potential. J Exp Med 2004; 200: 123-135.

[199] Kim JW, Kim SY, Park SY, et al. Mesenchymal progenitor cells in the human umbilical cord. Ann Hematol 2004; 83: 733-738.

[200] Wang H-S, Hung S-C, Peng S-T, et al. Mesenchymal stem cells in the Wharton's Jelly of the human umbilical cord. Stem Cells 2004; 22: 1330-1337.

[201] Wexler SA, Donaldson C, Denning-Kendall P, et al. Adult bone marrow is a rich source of human mesenchymal "stem" cells but umbilical cord and mobilized adult blood are not. Br J Haematol 2003; 121: 368-374

[202] Mareschi K, Biasin E, Piacibello W, et al. Isolation of human mesenchymal stem cells: bone marrow versus umbilical cord blood. Haematologica 2001; 86: 1099-1100.

[203] Yu M, Xiao Z, Li L. Mid-trimester fetal blood derived adherent cells share characteristics similar to mesenchymal stem cells but full-term umbilical cord does not. Br J Haematol 2004; 124: 666675

[204] Ryan JN, Barry FP, Murphy J, Mahon BP. Mesenchymal stem cells avoid allogeneic rejection. J Inflamm 2005; 2; 1-11.

[205] Devine SM, Cobbs C, Jennings M, Bartholomew A, Hoffman R Mesenchymal stem cells distribute to a wide range of tissues following systemic infusion into nonhuman primates. Blood 2003 101: 2999-3001

[206] Bartholomew A, Patil S, Mackay A, et al. Baboon mesenchymal stem cells can be genetically modified to secrete human erythropoietin in vivo. Human Gene Ther 2001; 12: 1527-1541.

[207] Devine SM, Bartholomew AM, Mahmud N, et al. Mesenchyma stem cells are capable of homing to the bone marrow of nonhuman primates following systemic infusion. Exp Heamatol 2001 29: $244-255$

[208] Tse WT, Pendleton JD, Byer WM, Egalka MC, Guinan EC Suppresion of allogeneic T-Cell proliferation by human marrow stromal cells: implications in transplantation. Transplantation 2003 ; 75: 389-397

[209] Le Blanc K, tammik C, Rosendahl K, Zetterberg E, Ringdén O. HLA expression and immunologic properties of differentiated and undifferentiated mesenchymal stem cells. Exp Hemat 2003; 31 890-896.

[210] Majumdar MK, Keane-Moore M, Buyaner D, et al. Characterization and functionality of cell surface molecules of human mesenchymal stem cells. J Biomed Sei 2003; 10: 228-241.
[211] Krampera R, Glennie S, Dyson J. Bone marroe mesenchyma stem cells inhibit the response of naïve and memory antigenspecific T cells to their cognate peptide. Blood 2003; 101:3722 3729.

[212] Aggarwal S, Pittenger MF. Human mesenchymal stem cells modulate allogeneic immune cell responses. Blood 2005; 105 $1815-1822$

[213] Horwitz EM, Gordon PL, Winston KK, et al. Isolated allogeneic bone marrow-derived mesencymal stem cells engraft and stimulate growth in children with osteogenesis imperfecta implications for cell therapy of bone. Proc Nat Acad Sci 2002; 99 8932-8937.

[214] Gotherstrom C, Ringden O, Tammik C, et al. Immunologic properties of human fetal mesenchymal stem cells. Am J Obste Gyncol 2004; 190: 239-245.

[215] Devine SM, Hoffman R. Role of mesenchymal stem cells in hematopoietic stem cells transplantation. Curr Opin Hematol 2000 7: 358-363.

[216] Zhang W, Ge W, Li C, et al. Effects of mesenchymal stem cells on differentiation, maturation, and function of human monocyte derived dendritic cells. Stem Cells Dev 2004; 13: 263-271.

[217] Beyth S, Borovsky Z, Mevorach D, et al. Human mesenchymal stem cells alter antigen presenting cell maturation and induce $T$ cell unresponsiveness. Blood 2005; 105: 2214-2219.

[218] Tamama K, Fan VH, Griffith LG, Blair HC, Wells A. Epidermal growth factor as candidate for ex vivo expansion of bone marrow-derived mesenchymal stem cells. Stem Cells 2005, in press.

[219] Cancedda R, Bianchi G, Derubeis A, Quarto R. Cell therapy for bone disease: a review of current status. Stem Cells 2003; 21:610 619.

[220] Gronthos S, Simmons PJ. The growt factor requirements of STRO-1 positive human bone marrow stromal precursors under serum deprived conditions in vitro. Blood 1995; 85: 929-940.

[221] Pitaru S, Kotev-Emeth S, Noff D, Kaffuler S, Savion N. Effect of basic fibroblast growth factor on the growth differentiation od adult stromal bone marrow cells: enhanced development of mineralized bone-like tissue in culture. J Bone Miner Res 1993; 919-929

[222] Lennon DP, Haynesworth SE, Young RG, dennis JE Caplan AI A chemically defined medium supports in vitro proliferation an maintains the osteochondral potential of rat marrow-derived mesenchymal stem cells. Exp Cell Res 1995; 219:211-222.

[223] Martin I, Muraglia A, Campanile G, Cancedda R, Quarto R Fibroblast growth factor-2 supports ex vivo expansion and maintenance of osteogenic precursors from human bone marrow. Endocrinology 1997; 138: 4456-4462.

[224] Bianchi G, Banfi A, Mastrogiacomo M, et al. Ex vivo enrichmen of mesenchymal cell progenitors by fibroblast growth factor 2 Exp Cell Res 2003; 287: 98-105.

[225] Solchaga LA, Penick K, Porter JD et al. FGF-2 enhances the mitotic and chondrogenic potentials of adult human bone marrow derived mesenchymal stem cells. J Cell Physiol 2005 203; 398 409.

[226] Kratchmarova I, Blagoev B, Haack-Sorensen M, Kassem M, Mann M. Mechanism of divergent growth factor effects in mesenchymal stem cells differentiation. Science $2005 ; 308: 1472$ 1477

[227] Baksh D, Davies JE, Zandstra PW. Adult human bone marrowderived mesenchymal progenitor cells are capable of adhesionindependent survival and expansion. Exp Hematol 2003; 31 : 723 732 